\title{
An Empirical Test of the Impact of Insurance on Income Inequality in Iran
}

\author{
Amir Mansour Tehranchian ${ }^{1}$ \\ Shahryar Zaroki ${ }^{2}$ \\ Nava Imani ${ }^{3}$
}

\author{
M.tehranchian@umz.ac.ir \\ Sh.zaroki@umz.ac.ir
}

\begin{abstract}
Emphasis on eliminating deprivation and poverty on the one hand and expanding insurance services on the other, confirms the fact that the concept of insurance has a key role for economic planners and policymakers in achieving the goal of reducing income inequality. The efforts made in the present study are aimed at improving the position of insurance in this field. In this regard, the impact of the insurance penetration coefficient on income inequality in 30 provinces of Iran during 2011-2015 has been calculated using the dynamic panel data in a basic model and two scenarios (based on human development index and insurance penetration coefficient). The results show that inflation has a positive effect on the Gini coefficient and consequently increases income inequality. However, per capita income index and insurance penetration coefficient have a negative effect on the Gini coefficient and lead to a decrease in income inequality. Furthermore, the effect of this factor on the Gini coefficient in provinces varies depending on the level of human development and insurance penetration coefficient level. So first, there is a significant difference in the extent of the influence of insurance penetration coefficient on the Gini coefficient in two groups of provinces in terms of human development level, so that an increase in the level of human development reinforces the effect of the insurance penetration coefficient on reducing income inequality. Second, there is a significant difference in the magnitude of the impact of insurance penetration coefficient on the Gini coefficient in the two groups of provinces in terms of insurance penetration coefficient level; Thus, by increasing the size of the insurance penetration coefficient, the influence of the insurance penetration coefficient on reducing income inequality is strengthened.
\end{abstract}

Keywords: Income Distribution, Insurance Penetration Coefficient, Panel Data, Per Capita Income, Human Development Index, Iran.

JEL Classification: D31, E21, G22.

\footnotetext{
1. Associate Professor, Department of Economics, Faculty of Economic and Administration Sciences, University of Mazandaran, Babolsar, Iran, (Corresponding Author).

2. Assistant Professor, Department of Economics, Faculty of Economic and Administration Sciences, University of Mazandaran, Babolsar, Iran.

3. M.A. in Economics, Allameh Mohaddes Nouri University, Nūr, Iran.
} 


\section{آزمون تجربى تاثير بيمه بر نابر ابرى درآمد در ايران}

m.tehranchian@umz.ac.ir

sh.zaroki@umz.ac.ir

مقاله بزوهشى
| اميرمنصور طهرانجيان دانشيار گروه اقتصاد، دانشكده اقتصاد و علوم ادارى، دانشَاه

مازندران (نويسنده مسئول).

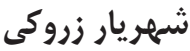
استاديار كروه اقتصاد، دانشكده اقتصاد و علوم ادارى، دانشگاه مازندران. - مان.

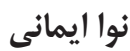
كارشناسى ارشد اقتصاد دانشكاه علامه محدث نورى.

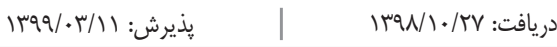

קكيده: از يكسو، تاكيد بر رفع محروميت و فقر، و از سوى ديكر گسترش خدمات بيمهاى بيانكر

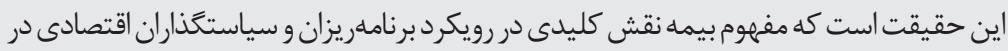

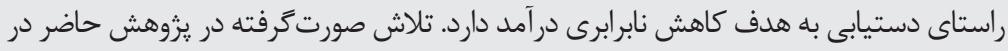

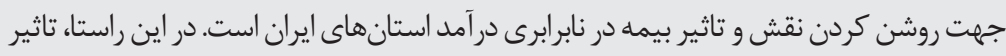

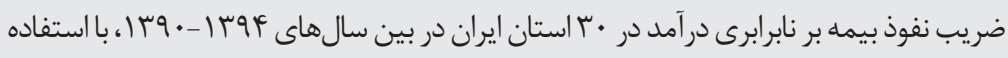

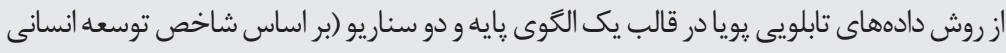

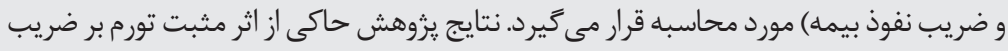

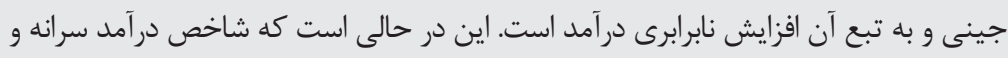

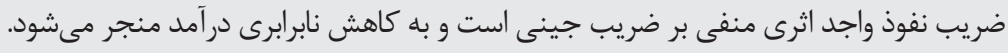

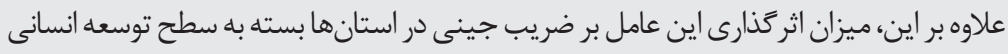

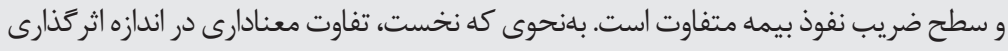

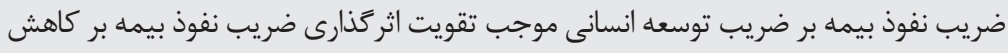

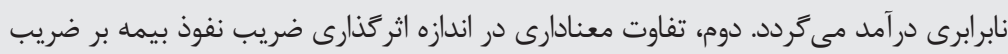

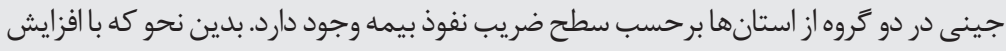

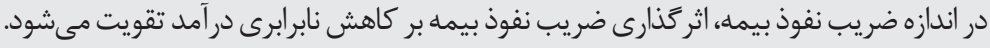

كليدوازهها: توزيع درآمد، ضريب نفوذ بيمه، دادهاى تابلويى يويا، درآمد سرانه، شاخص توسعه انسانى، ايران. طبقهبندى G22, E21, D31 :JEL. توسعه أنساني 
با توجه به اهميتى كه ناطمينانى و ريسك در ميزان و شدت سرمايهگذارى اقتصادى دارد، و

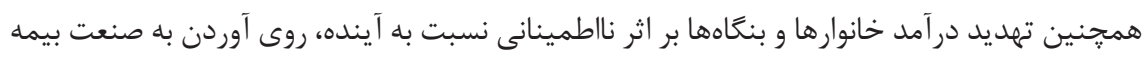

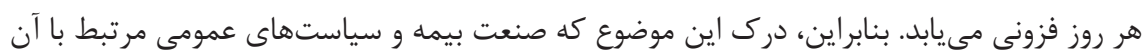
تا جه اندازه در سنجش بهزيستى اقتصادى و نابرابرى در جامعه نقش دارند، مههم است. صنعت بيمه

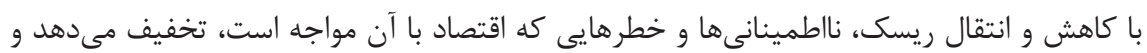
زمينهساز افزايش شتاب در رشد اقتصادى مىشود (ميرزايى و همكاران، سوسا). در واقع، بيمههاى اجتماعى با تحريك عرضه و تقاضا و همجنين با افزايش رشد اقتصادى بـ بر توزيع در آمد توانا هستند. از

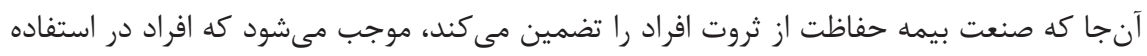
از دارايى خود در بخشهاى مختلف اقتصادى، ريسك پـذيرى بيشترى داشته باشند كه اين امر رشد

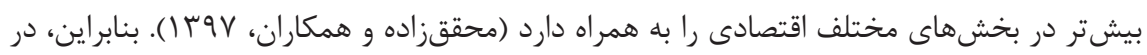

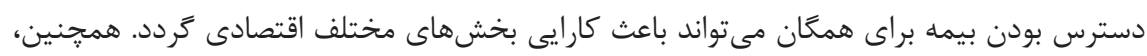

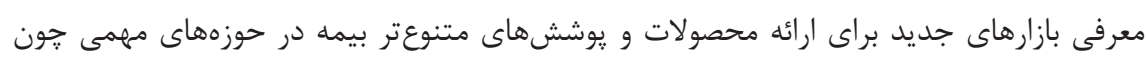
بخش كشاورزى، داميرورى، و ساختوساز سبب افزايش سرمايهَذارى در اين حوزهها مى شوده، و و

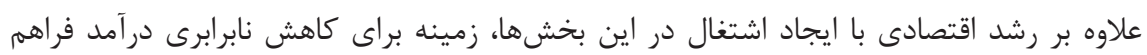

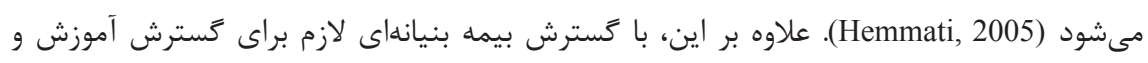

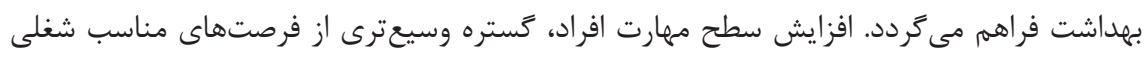

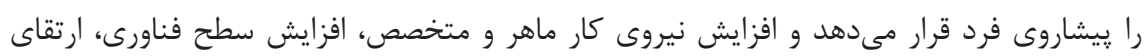

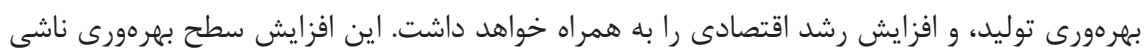

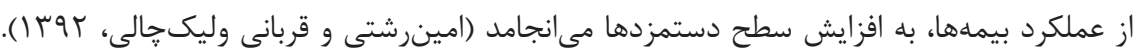

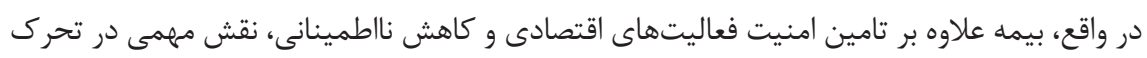

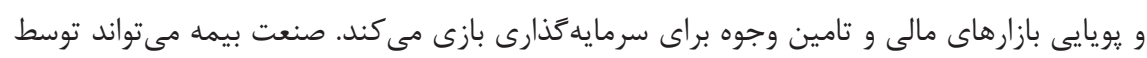

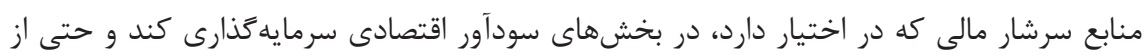

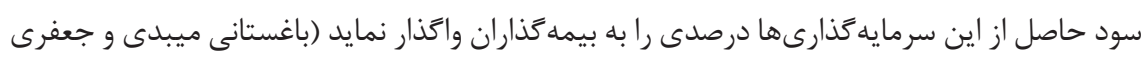

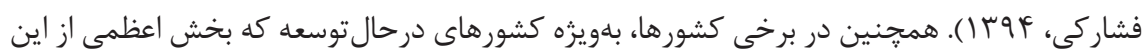

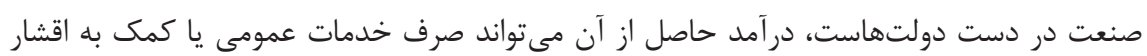

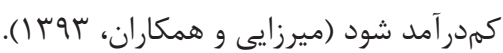


بر اساس اين، يزوهش حاضر نخست در بي كشف كيفيت تاثيرگذارى بيمه بر نابرابرى درآمد

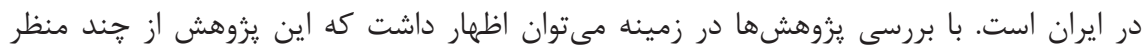

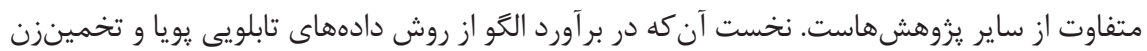

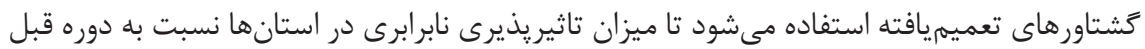

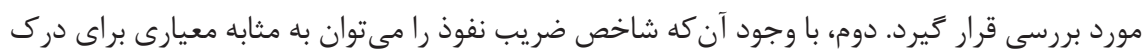

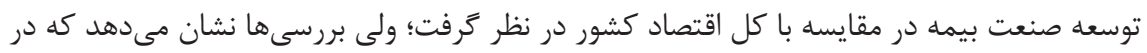

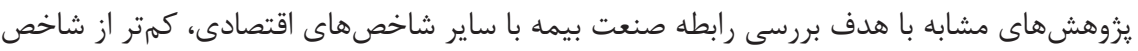

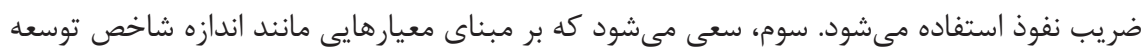

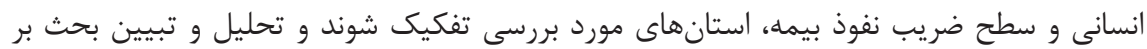

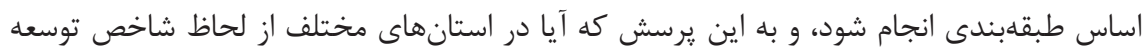

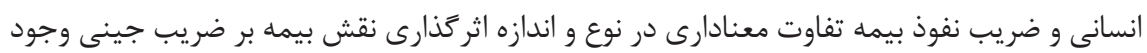
دارد يا خير، ياسخ داده شود.

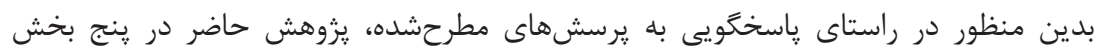
سازماندهى مىشود. در بخش نخست، به مرور مبانى نظرى يزوهش يرداخته مى شود. در بخش دوم،

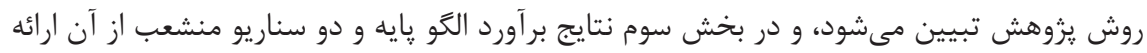

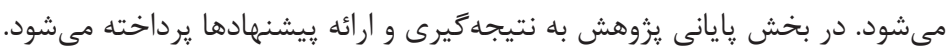

\section{مبانى نظرى يُزوهش}

از مفهوم نابرابرى درآمد به عنوان يديدهاى در تضاد با عدالت اجتماعى و عاملى براى جرم، جنايت، فقر و محروميت اجتماعى ياد مىشود (زيبايى، ع/با(). نابرابرى درآمد زمينهساز تفاوت در عادات شخصى، شرايط محيطزيست، آموزش، و دسترسى به مراقبتهاى بهداشتى مى محرود كه اين عوامل به تفاوت در ميزان اميد به زندگى ميان افراد مختلف منجر ميى كردد (Gordon \& Becker, 2016).

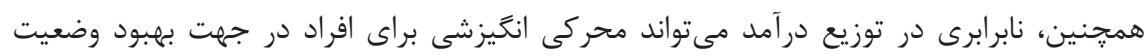
خود از طريق كار، نوآورى يا كسب مهارتهاى جديد باشد (Eurostat, 2016)'. بررسى نحوه تاثير و دورئ

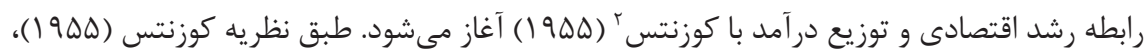

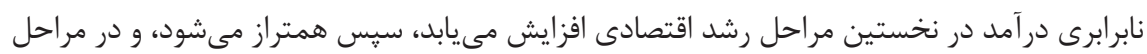


بعدى رشد كاهش مى يابد (نيلى و فرحبخش، IrVV). الكوى توزيع درآمد كوزنتس (9DQ ())، تركيبى

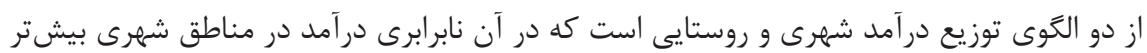

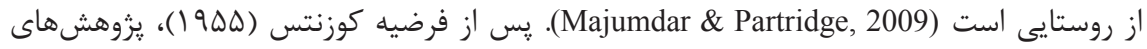
گَسترداى در زمينه تاثير رشد اقتصادى بر نابرابرى درآمد صورت گرفته است كه با توجه به شرايط

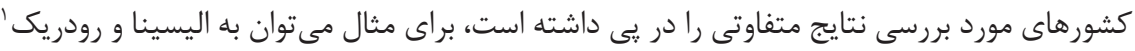

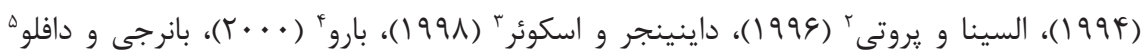

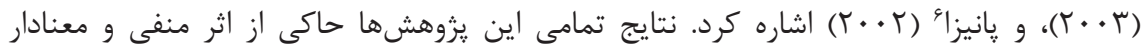

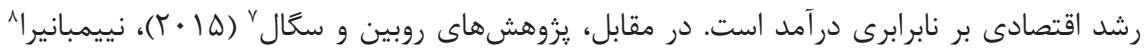

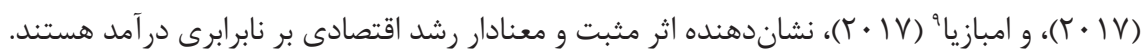

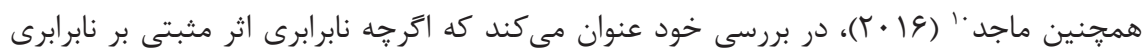

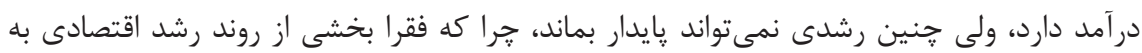

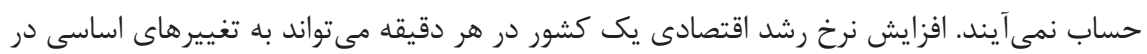

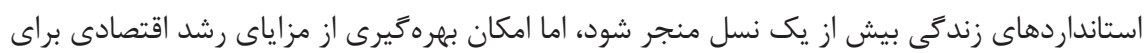

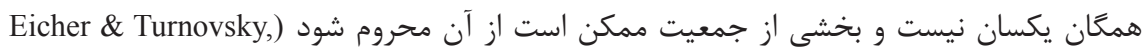
2003). بنابراين، ايجاد يك نظام اجتماعى كارامد و عدالتمحور كه بتواند به توزيع بهتر درآمد مند منجر

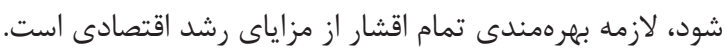

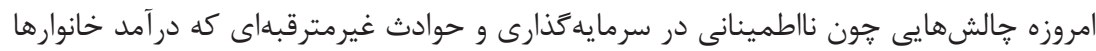
و بنكًاهها را تهديد مى كند، و افزايش نياز به كارويزه حمايتى بيمهها در راستاى فائق آمدن بر اين

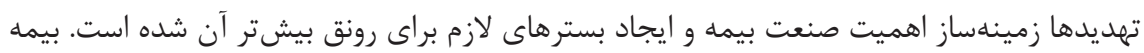

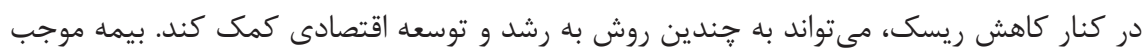

\section{Alesina \& Rodrick}

2. Alesina \& Perotti

3. Deininger \& Squire

4. Barro

5. Banerjee \& Duflo

6. Panizza

7. Rubin \& Segal

8. Niyimbanira

9. Mbazia

10. Majeed 
مىشود صاحبان مشاغل با نوسانها و ريسك كمترى كار كنند. شركتهاى بيمه خصوصى مى توانند

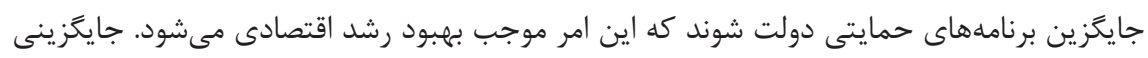

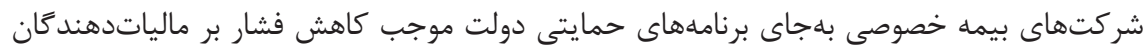

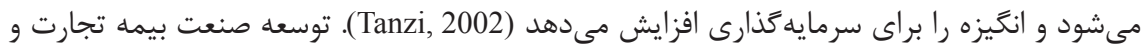

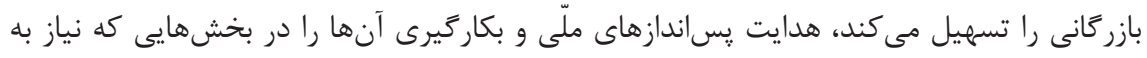

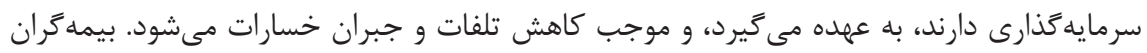

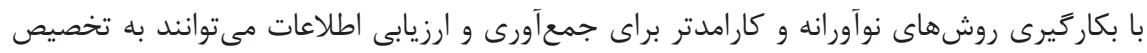

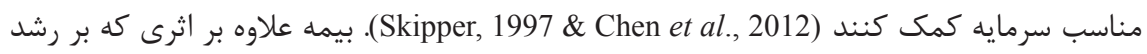

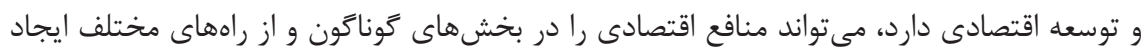

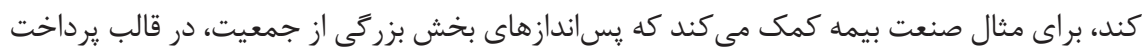

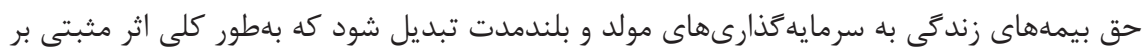

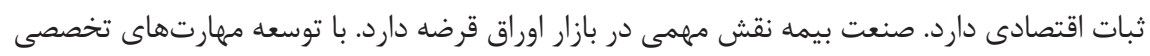

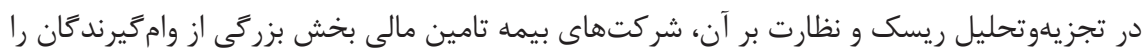

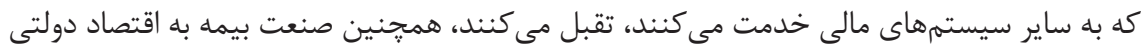

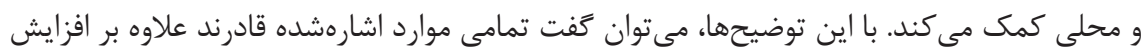

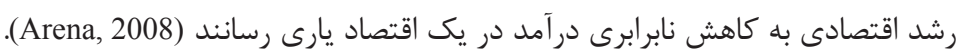

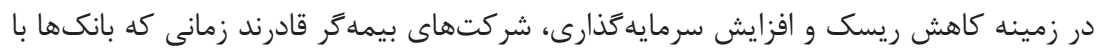

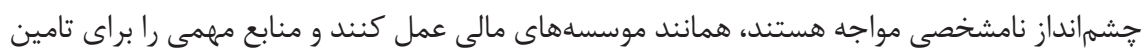

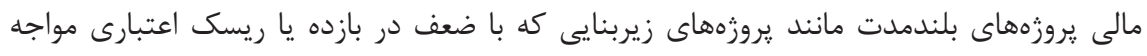

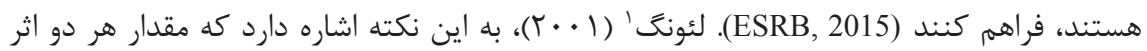

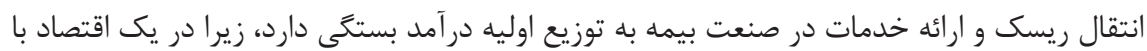

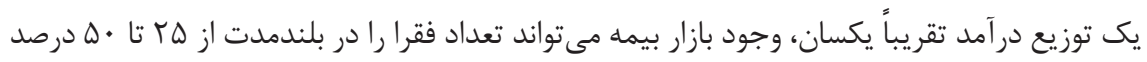

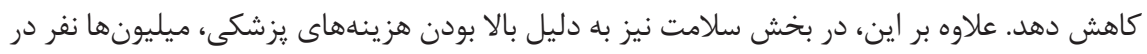

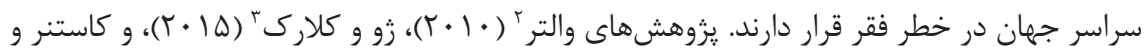

1. Leung 


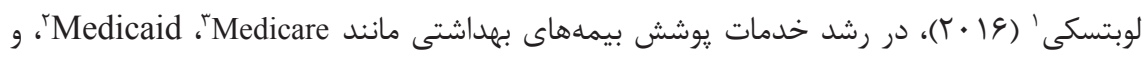

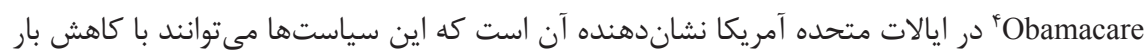

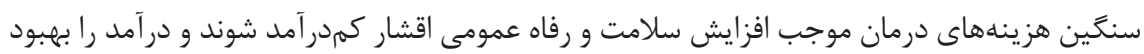

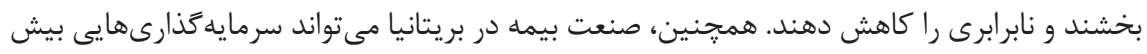

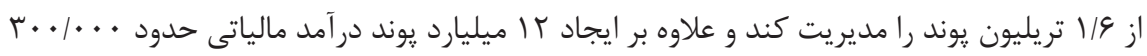
موقعيت شغلى را نيز فراهم كند (ABA, 2016)ه.

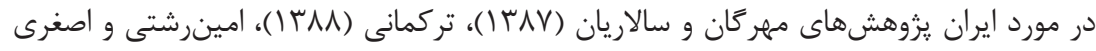

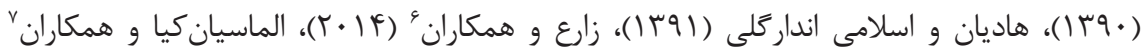

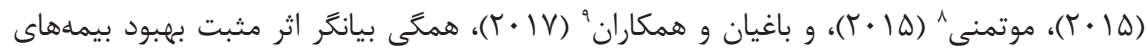

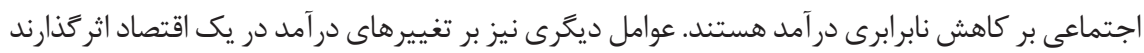

\section{Kaestner \& Lubotsky}

ז. يك برنامه مشترك فدرالى و ايالتى در ايالاتمتحده آمريكا وجود دارد كه هزينههاى يزشكى را براى برخى از

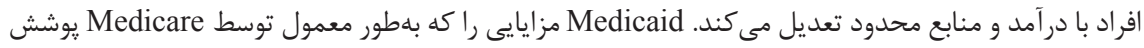

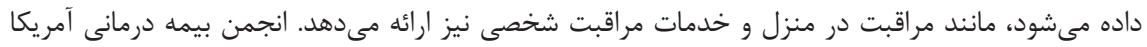

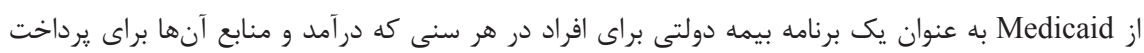

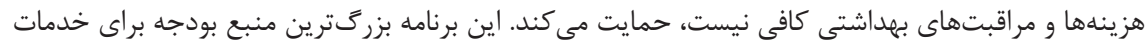

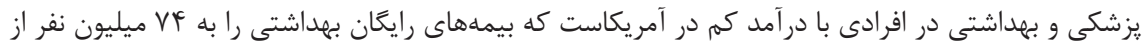

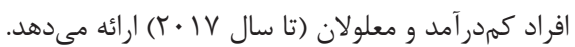

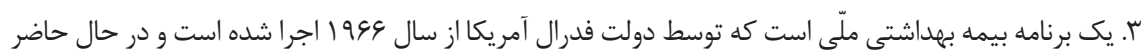

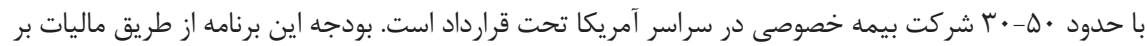

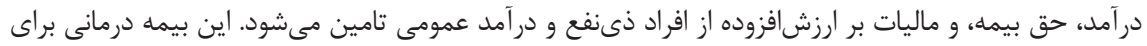

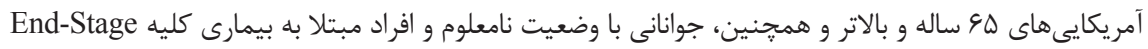

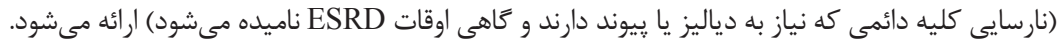

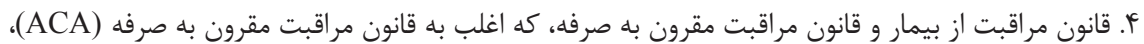

5. Association of British Insurers

6. Zare et al.

7. Almasiankia et al.

8. Motameni

9. Baghian 
كه از مهمترين عوامل مىتوان به شاخص تورم اشاره كرد. تورم و توزيع نابرابر درآمد از جمله عواملى هستند كه باعث افزايش فساد در جامعه مىشوند. فساد در يك اقتصاد همواره اثرى منفى دارد و از عوامل

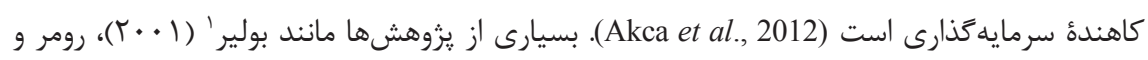

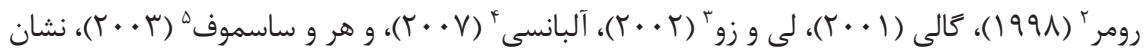

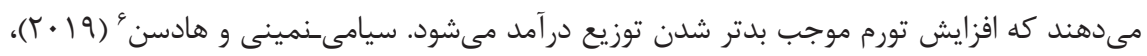

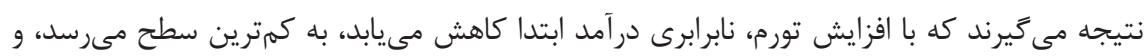

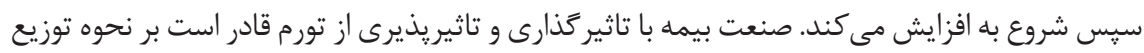

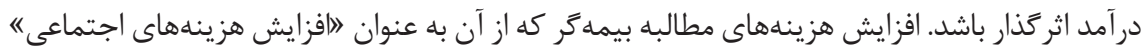

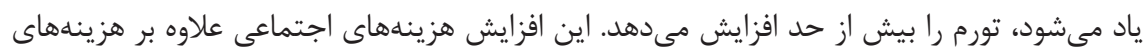
تورم شامل اثرهاى افزايش دادرسى، تغييرها در هنجارهاى اجتماعى، و افزايش در هزينههاى خدى خدمات

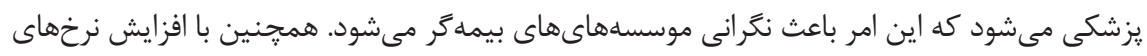

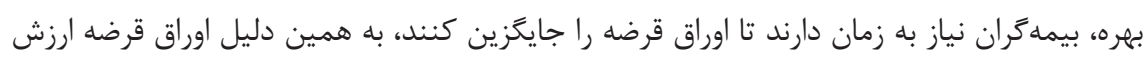

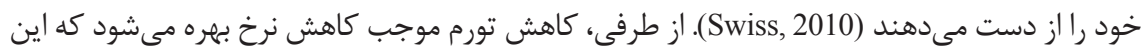
امر كار را براى موسسههاى بيمهَر عمر با يرتفوىهاى بزرى كه با كمترين نرخ بهره توليد يسانداز را

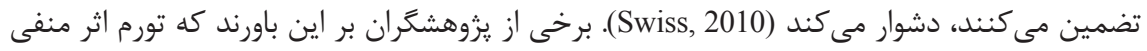

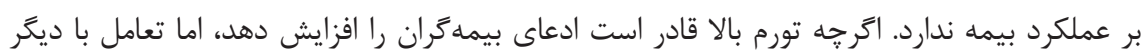

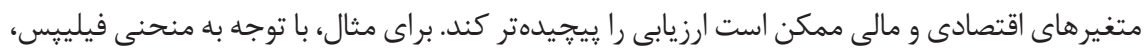
زمانى كه بيمهكر در مواجهه با تورم مطالبات خود را افزايش مىدهد، اين اثرها را مىتوان با بيكارى هايينتر جبران كرد.

1. Bulír

2. Romer \& Romer

3. Li \& Zoo

4. Albanesi

p)

5. Heer \& Süssmuth

6. Siami-Namini \& Hudson 


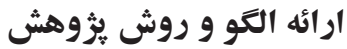

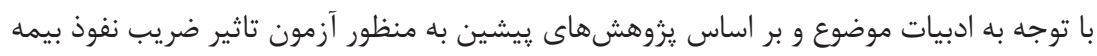

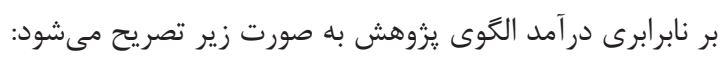

$\operatorname{LnGini}_{i, t}=\alpha_{i}+\theta \operatorname{LnGini}_{i, t-1}+\beta_{1} \operatorname{LnInsur}_{i, t}+\beta_{2} \operatorname{LnCpi}_{i, t}+\beta_{3} \operatorname{LnPci}_{i, t}+\varepsilon_{i, t}$

كه در آن Gini متغير وابسته است كه از آن به عنوان ابزارى بـراى سنجش نابرابرى توزيع درآمد

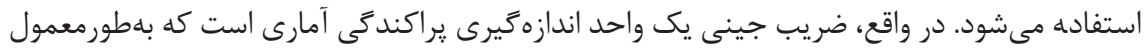

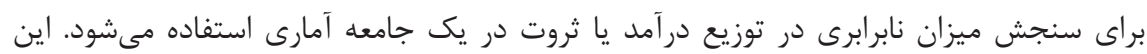

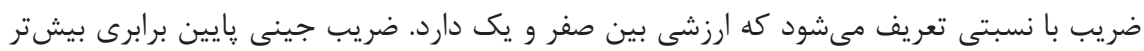

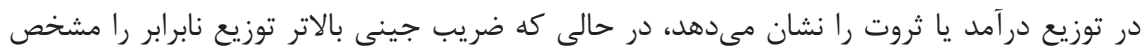

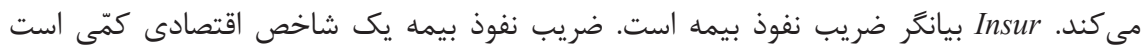

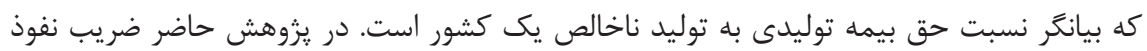

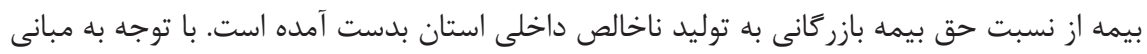

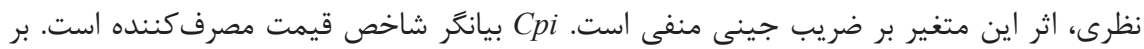

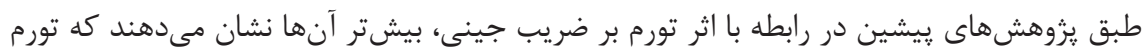

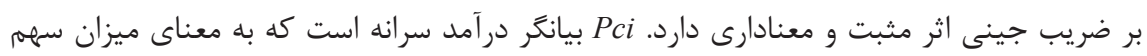

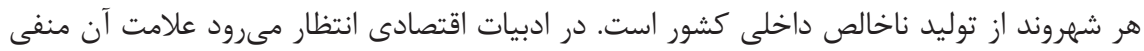

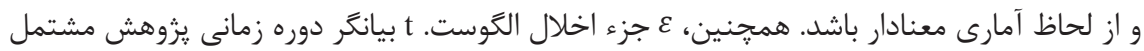

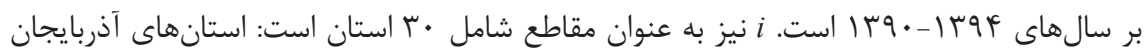

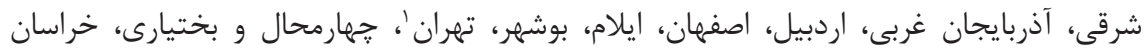

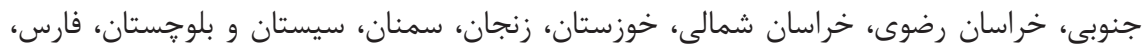

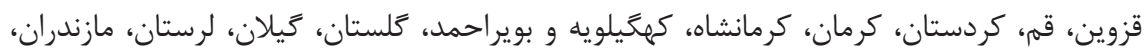

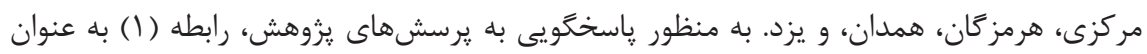

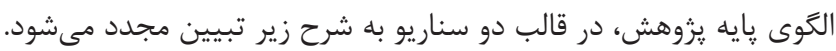

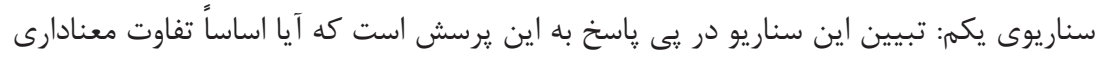


ميان استانهايى با شاخص توسعه انسانى بالا با ساير استانها به لحاظ نوع و اندازه اثر خذارى ضريب نفوذ بر ضريب جينى وجود دارد يا خير؟ رابطه رگرسيونى براى اين سناريو به صورت زير تصريح

$\operatorname{LnGini}_{i, t}=\alpha_{i}+\theta \operatorname{LnGini}_{i, t-1}+\beta_{1} \operatorname{LnInsur}_{i, t}+\beta_{2} \operatorname{LnCpi}_{i, t}+\beta_{3} \operatorname{LnPci}_{i, t}+$ $\beta_{4} D_{1}$ LnInsur $_{i, t}+\varepsilon_{i, t}$

$D_{1}=\left\{\begin{array}{l}0 \\ 1\end{array}\right.$

$H d i<1 / 74$

كه در آن D به صورت زير تعريف مىشود:

Hdi $>1 / 74$

استانهايى با توسعه انسانى بالاتر از ميانگين (I/VF) شامل تهران، اصفهان، ايلام، بوشهر، קهارمحال و بختيارى، خراسان رضوى، خوزستان، سمنان، فارس، قزوين، قم، كرمان، كَلستان، كيلان، مازندران، مركزى، و يزد مىشود و براى ساير استانها ميزان شاخص كمتر از ميانگَين است. معنادارى

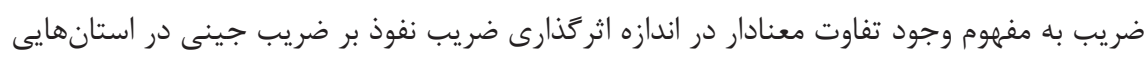
با شاخص توسعه انسانى بالا نسبت به ساير استانهاست.

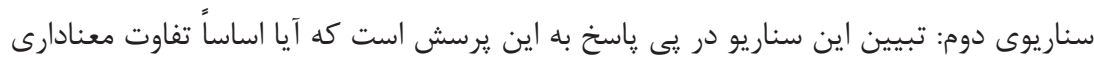

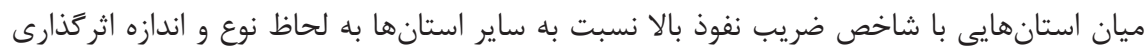

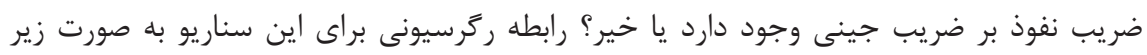

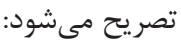

$\operatorname{LnGini}_{i, t}=\alpha_{i}+\theta \operatorname{LnGini}_{i, t-1}+\beta_{1} \operatorname{LnInsur}_{i, t}+\beta_{2} \operatorname{LnCpi}_{i, t}+\beta_{3} \operatorname{LnPCi}_{i, t}+$ $\beta_{4} D_{2}$ LnInsur $_{i, t}+\varepsilon_{i, t}$

$D_{2}=\left\{\begin{array}{l}0 \\ 1\end{array}\right.$

استانهايى با ضريب نفوذ بالاتر از ميانگين (V/•) شامل آذربايجان شرقى، آذربايجان غربى، اردبيل، تهران، جهارمحال و بختيارى، خراسان رضوى، خراسان جنوبى، خراسان شمالى، زنجان،

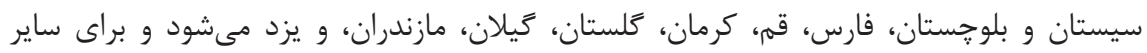

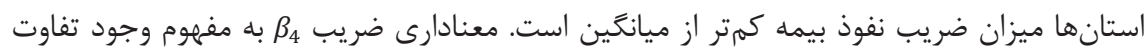

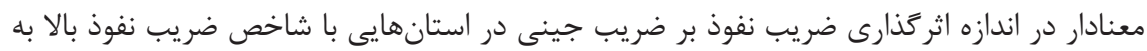




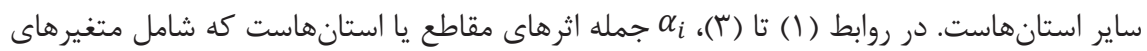
مشاهدهنشه و غيرقابلاندازهيرى اثركذار بر ضريب جينى استانهاست مانند، فرهنگ، شرايط

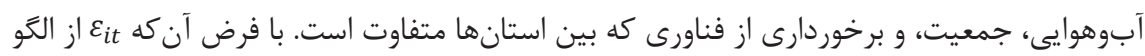
جزء اخلال يكىطرفه يِيروى مى كند (به عبارتى، تنها يك عامل موجب تفاوت مقطع مىشود و آن الخوى اثرهاى ثابت است)، مى توان نوشت:

$\varepsilon_{i, t}=\mu_{i}+v_{i, t}$

كه در آن

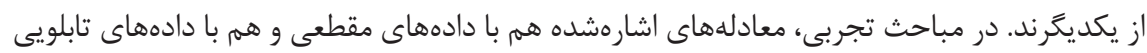

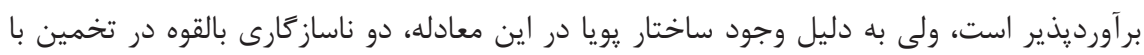
دادههاى مقطعى وجود دارد. نخست، تورش ناشى از حذف متغير و دوم، تورش ناشى از درونزايى.

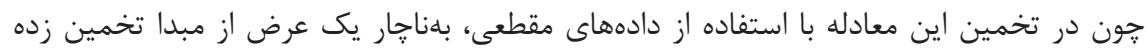

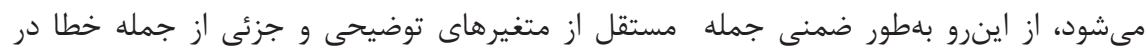

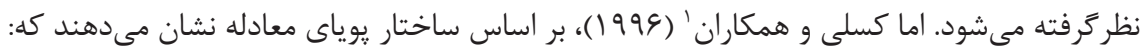

$E\left(\alpha_{i} . Y_{i, t-1}\right)=E\left[\alpha_{i} \cdot\left(\alpha_{i}+\beta_{t-1}+\gamma X_{i, t-1}+\theta Y_{i, t-1}+\varepsilon_{i, t-1}\right)\right] \neq 0$

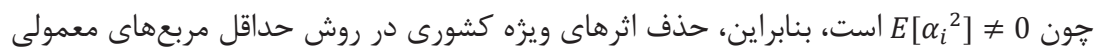

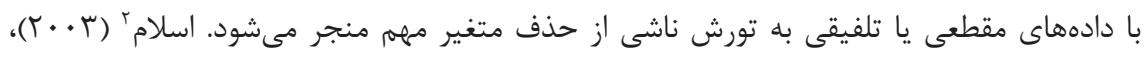

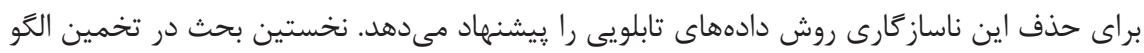

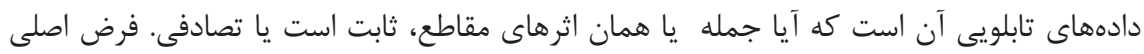
در الكوى اثرهاى تصادفى اين است كه اثرهاى مقاطع، مستقل از متغيرهاى توضيحى هستند. اسلام

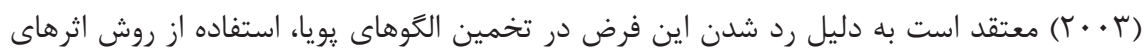

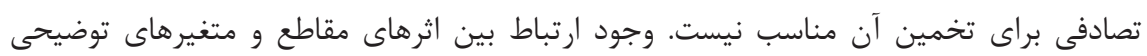
در روش اثرهاى ثابت مشكلزا نيست، اما اين روش نمىتواند مشكل تورش درونزايى متغيرهاى

1. Caselli et al.

2. Islam 
توضيحى را حل كند. از سوى ديكر، به دليل وجود ساختار يويا در الكو، هسيائو' (911)، و آرلانو

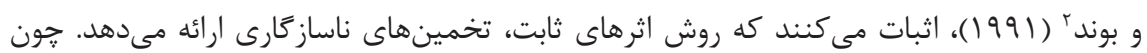

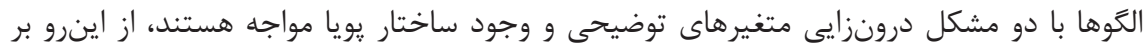
اساس بالتاجى" (1 · ·r)، و آرلانو و بوند (1991)، بايد به روش حداقل مربعهاى دومرحلهاى يا به

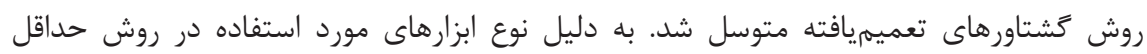

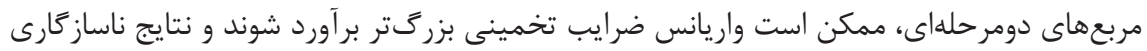
بهدست آيد. از اينرو، مناسبترين تخمينزن براى الكَوهاى يوياى تابلويى، تخمينزن گشتاورهاى

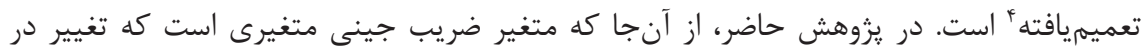
آن به كندى انجام مىشود و به نظر مىرسد متغيرى كه مقدارش به دلايل ساختارى شكل بخيرد، جندان نسبت به متغيرهاى ديگر واكنش نشان نمىدهد، براى تخمين الكوى يوياى تابلويى از روش گَشتاورهاى تعميميافته استفاده مىشود تا ميزان تاثيريذيرى نابرابرى در استانها نسبت به دوره قبل مورد بررسى قرار گيرد.

\section{دادهها و بر آورد التو}

در اين زيزوهش، كليه دادههاى آمارى و اطلاعات مورد نياز به روش كتابخانهاى جمعآورى مىشود. دادههاى مربوط به شاخص قيمت از سايت بانك مركزىه، دادههاى مربوط به در آمد سرانه و ضريب جينى از سايت مركز آمار ايران'؛ و دادههاى مربوط به ضريب نفوذ بيمه از سايت بيمه مركزى

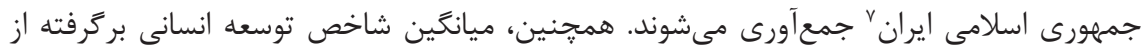

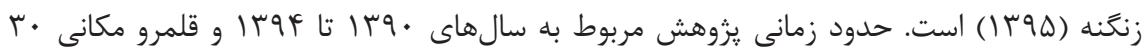
استان كشور است. در اين بخش، براى شناخت بيشتر دادها، ميانگين متغيرها در استانهاى مورد

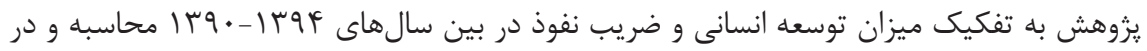

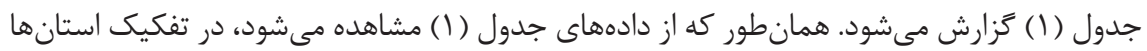

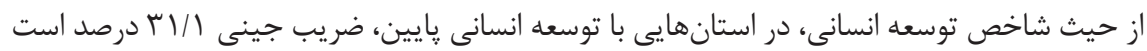

1. Hsiao

2. Arellano \& Bond

3. Baltagi

4. Generalized Method of Moments (GMM)

5. https://www.cbi.ir/simplelist/1591.aspx 
كه نسبت به استانهايى با توسعه انسانى بالا با ميانكين ضريب جينى / /T نابرابرى درآمد كمترى

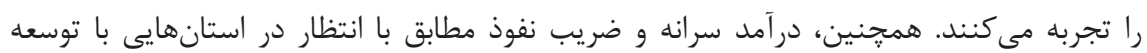
انسانى يايين كمتر از استانهايى با شاخص توسعه انسانى بالاست. در تقسيمبندى استانها بر اساس سطح شاخص ضريب نفوذ مىتوان اظهار داشت كه در استانهايى كه داراى ضريب نفوذ بالا هستند،

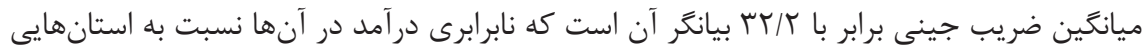

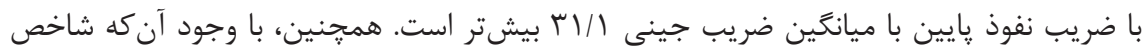

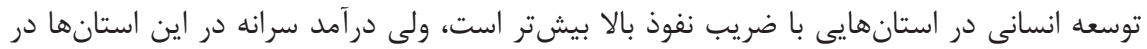

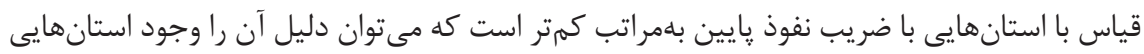
با منابع عظيم نفت و كاز در بين آنها دانست.

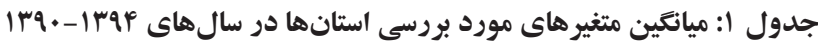

\begin{tabular}{|c|c|c|c|c|}
\hline توسعه & در (هزار ريال) & ضريب نفوذ & ضريب & 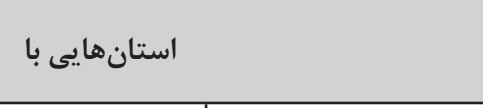 \\
\hline$\cdot|V M|$ & $1 \Delta \Delta \Delta \cdots$ & $1 / V 9$ & $r T / l$ & تفكيك استانها بر اساس : : توسعه انسانى بالا \\
\hline$\cdot 19 \Delta 1$ & $\wedge 9091$ & $1 / V 9$ & ri/l & شاخص توسعه انسانى : : توسعه انسانى يايين \\
\hline$\cdot / V \cdot 1$ & ११६qr & $r / 11$ & $r T / T$ & تفكيك استانها بر اساس : \\
\hline$\cdot 1991$ & 19VV9V & $1 / T F$ & rI/l & 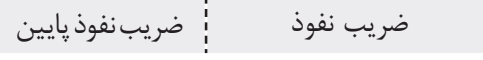 \\
\hline $.199 \mathrm{~V}$ & $11 \cdot V I V V$ & $1 / V 1$ & ri/s & ميانگين كل استانها \\
\hline
\end{tabular}

براى بررسى روند حركتى ضريب نفوذ و ضريب جينى بر مبناى دو ملاك تفكيك استانها

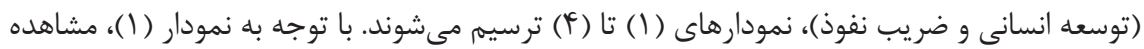
مىشود كه ميانگين ضريب جينى براى استانهايى با توسعه انسانى بالا با نوسان بسيارى همراه است.

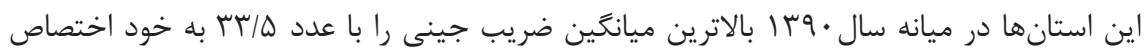

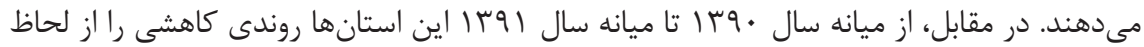

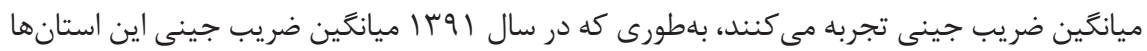
پايينتر از ميانگين ضريب جينى استانهايى با توسعه انسانى كمتر است. اين روند كاهشى تا ميانه

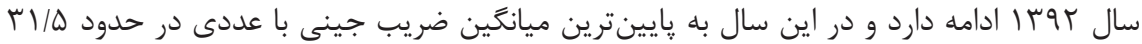

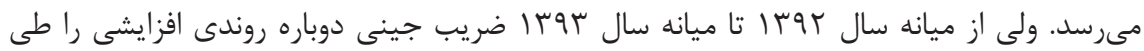




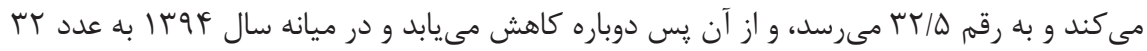

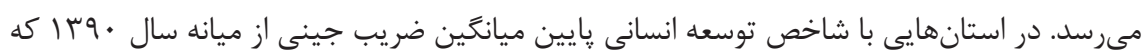
بالاترين ميانكين ضريب جينى با عدد سب را دارند، با شيب بهنسبت تندى كاهش ميى يابد كه اين روند

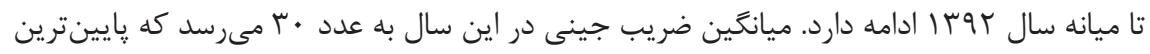

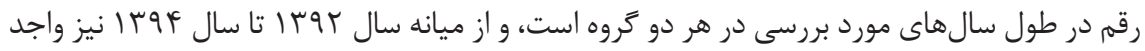

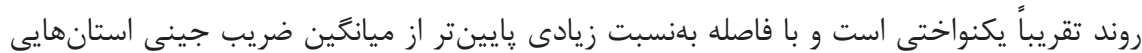

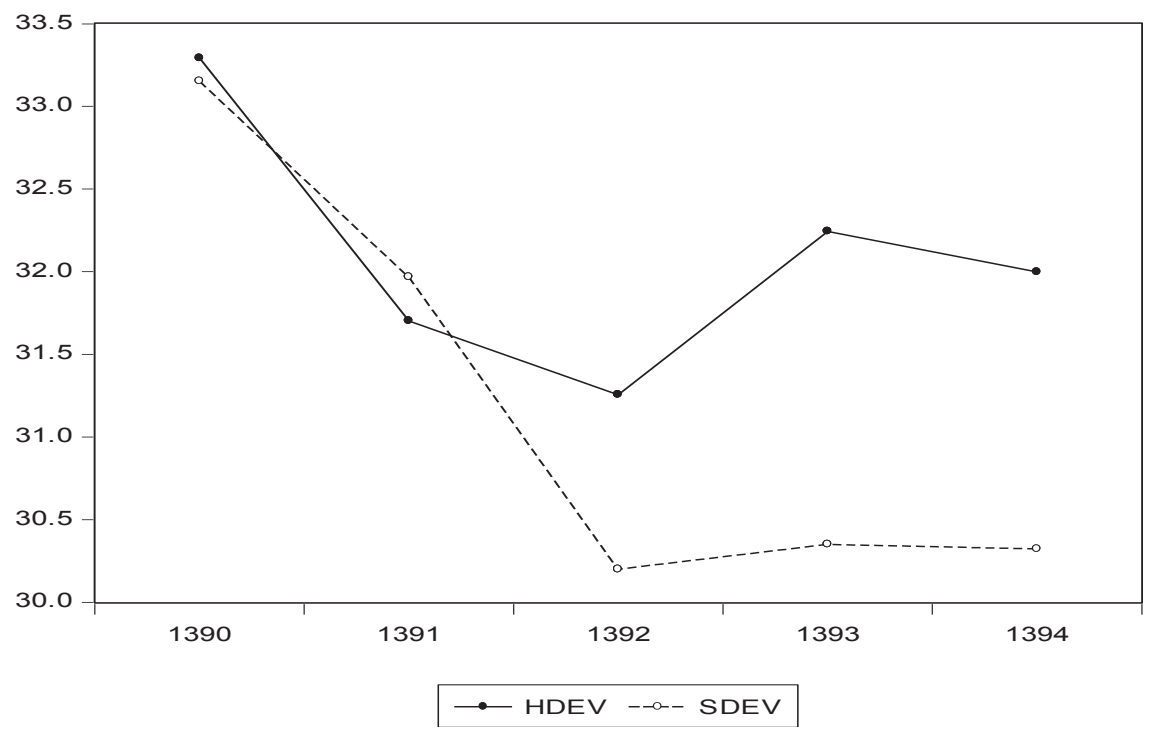

نمودار ا: ميانعين ضريب جينى بر مبناى شاخص توسعه انسانى'

با مشاهده نمودار (Y)، مىتوان كَفت ميانگين ضريب نفوذ بيمه براى استان هايى با شاخص توسعه

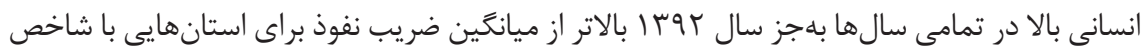

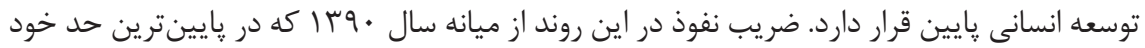

1. در تمامى نمودارها، استانهايى با توسعه انسانى و ضريب نفوذ بالا توسط خط ممتد و استانهايى با توسعه

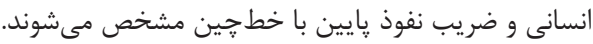


و در عدد س/ درصد قرار دارد، تقريباً برابر با ميانگين ضريب نفوذ استانهايى با توسعه انسانى پايين

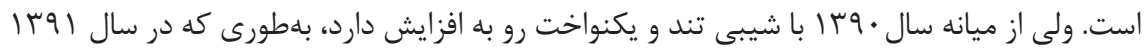

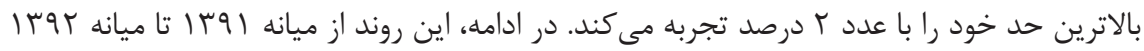

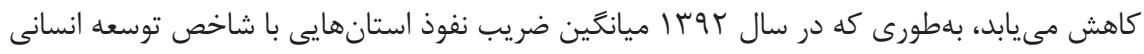

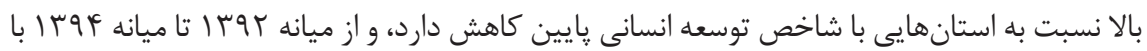

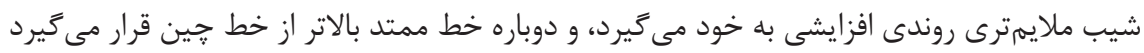

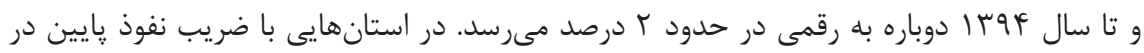

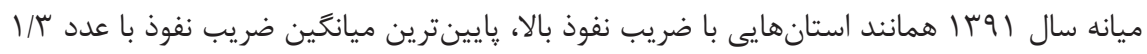

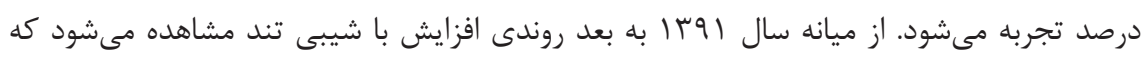

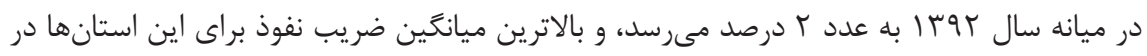

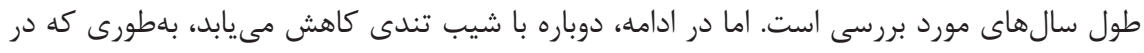

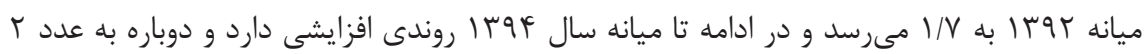

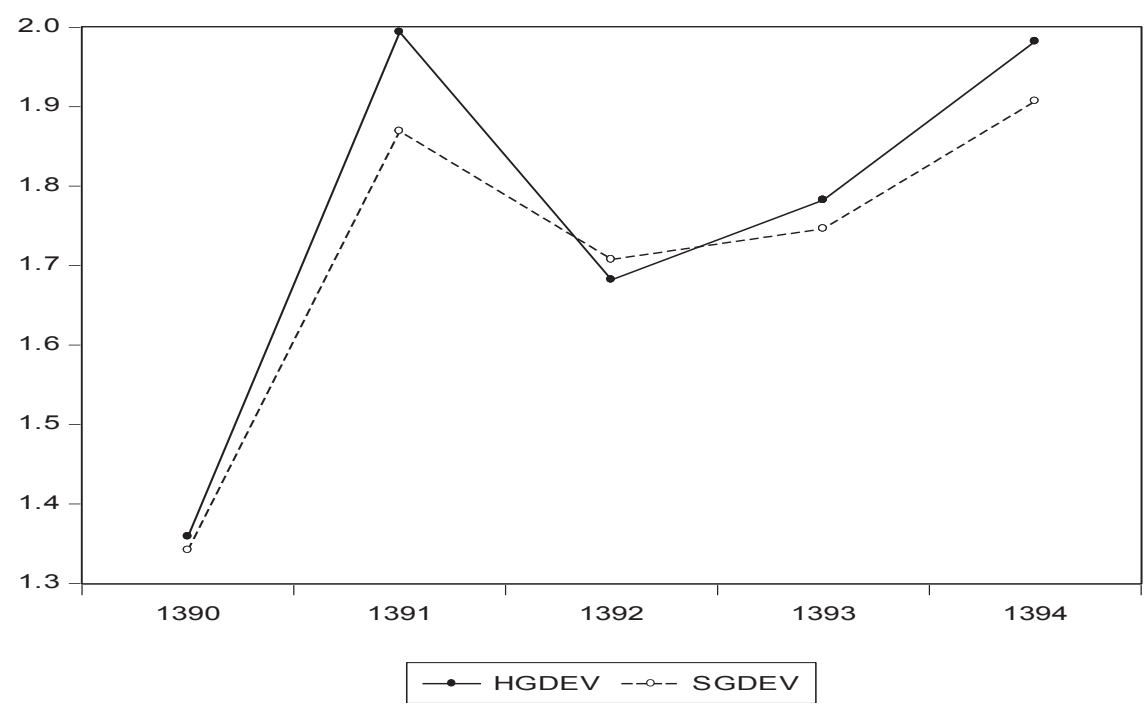


در نمودار (ب)، ميانگين ضريب جينى استانهايى كه بر مبناى شاخص ضريب نفوذ در رده بالاترى

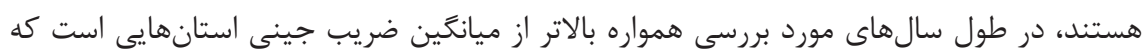

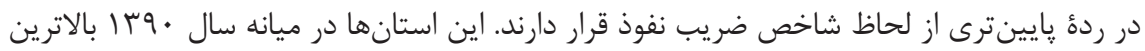

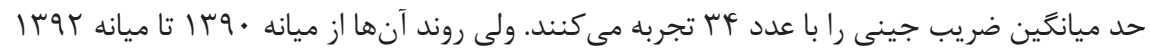

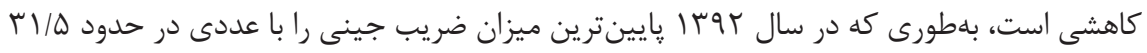

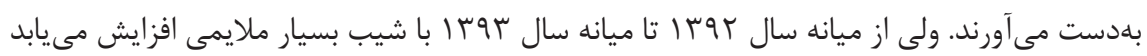

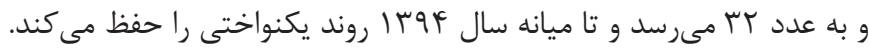

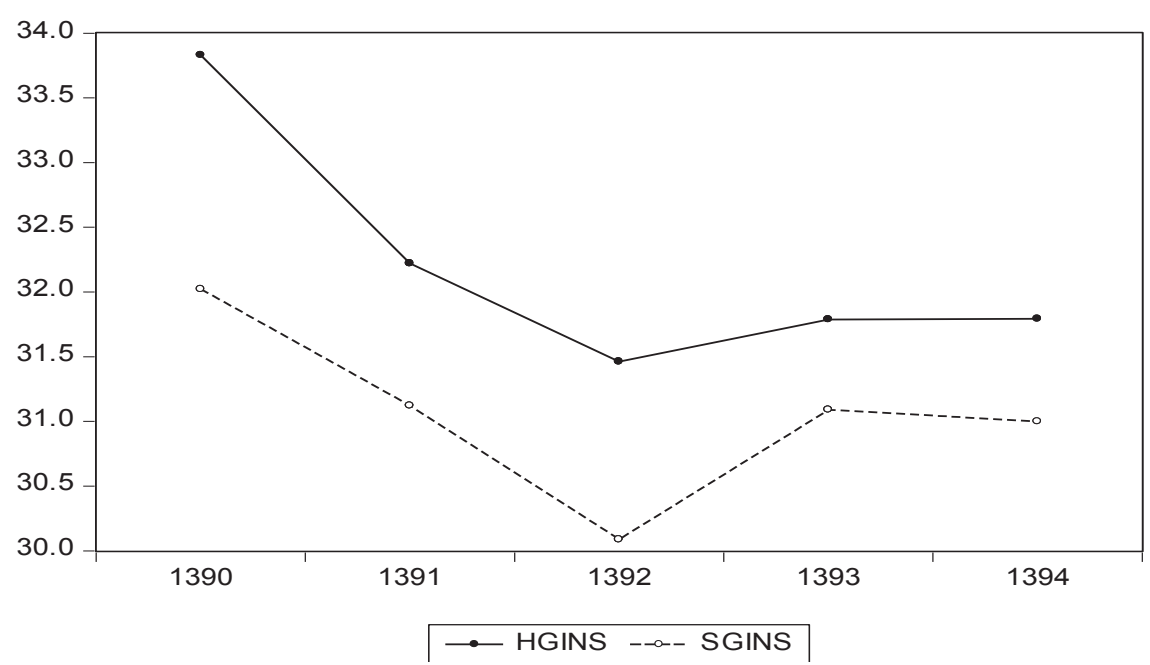

نمودار "ז: ميانغين ضريب جينى بر مبناى شاخص ضريب نفوذ

ميانگين ضريب جينى استانهايى كه بر مبناى شاخص ضريب نفوذ پايين قرار دارند، در ميانه

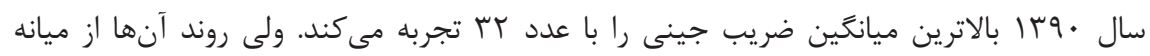

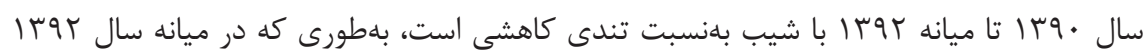
يايينترين ميزان ميانگين ضريب جينى را با عددى در حدود ·r بهدست مى آورند. ولى ميانكَين

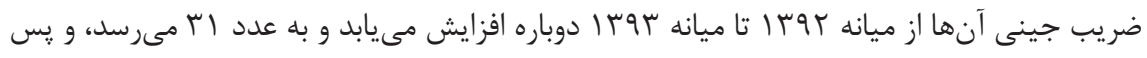


نمودار (1)، نشان مى دهد كه ميانگين ضريب نفوذ براى استانهايى با شاخص ضريب نفوذ بالا

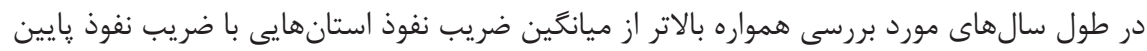
قرار دارد. ميانگين ضريب نفوذ در اين استانها در ميانه سال •وجا در يايينترين سطح به ميزان مران

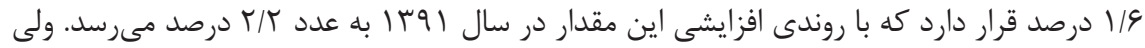

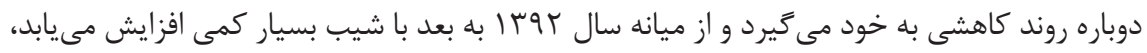

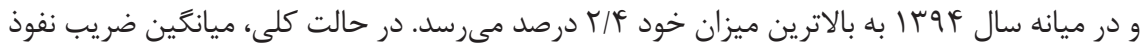

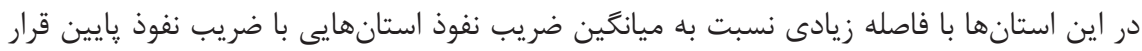

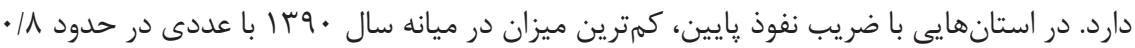

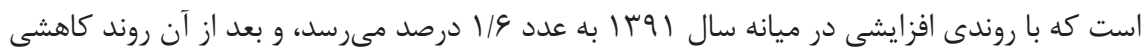

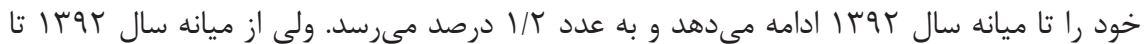

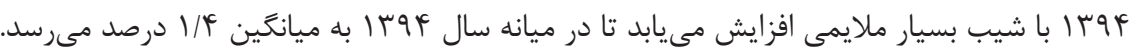

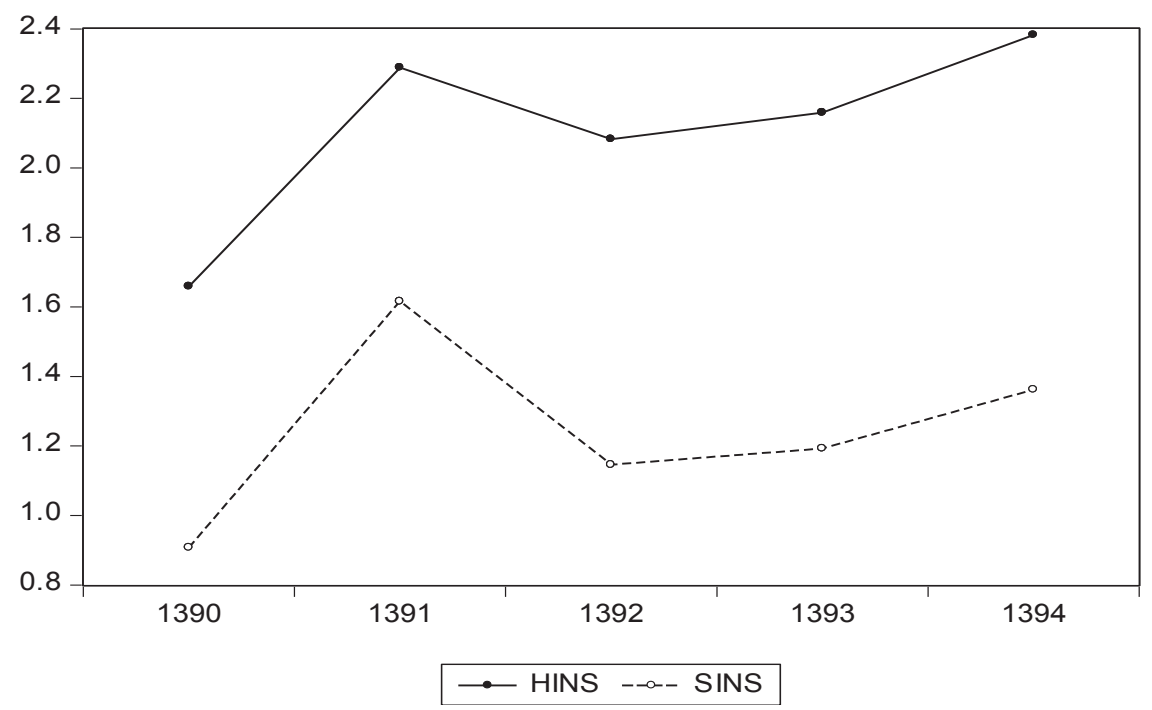

نمودار ٪ا: ميانكين ضريب نفوذ بر مبناى شاخص ضريب نفوذ 


\section{بر آورد الكو و ارائه نتايج'}

نتايج آزمون آرلانو-باند در جدول (r)، بيانگر يذيرفته نشدن فرضيه صفر در مرتبه يكم و وذيرش آن در مرتبه دوم در تمامى برآوردهاست. بنابراين، نبود خودهمبستگى جمله هاى اخلال در برآ آوردها

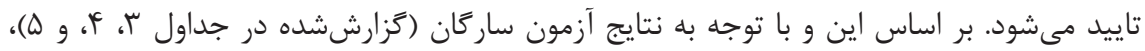
اعتبار الخو در سه برآورد صورتگرفته تاييد مى گردد.

جدول r: نتايج آزمون خودهمبستكى آرلانو-باند در برآوردها

\begin{tabular}{|c|c|c|c|c|}
\hline سناريوى دوم & سناريوى يكم & الكَىى يايه & & \\
\hline$-r / \Lambda r$ & $-Y / Q F$ & $-r|q|$ & آماره آزمون & \multirow{2}{*}{ مرتبه يكمم } \\
\hline$\cdot / \cdot \cdot r$ & $.1 \cdot 11$ & $\cdot 1 \cdot \cdot r$ & سطح احتمال & \\
\hline$-1 / 9 \Delta$ & $-1 / 19$ & VA/I- & آماره آزمون & \multirow{2}{*}{ مر تبه دوم } \\
\hline .1 .91 & . ITFT & $\cdot 1 \cdot \vee \Delta$ & سطح احتمال & \\
\hline
\end{tabular}

نتايج نهايى برآورد الكوهاى مورد نظر با روش گشتاورهاى تعميهيافته در جداول (Y)، (I)، و (ه)

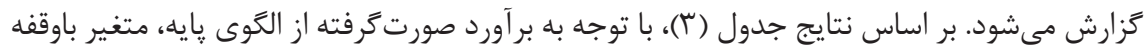

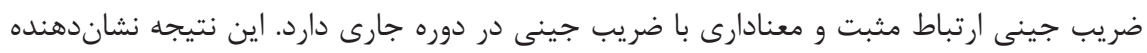

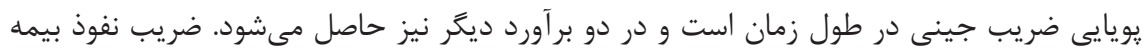

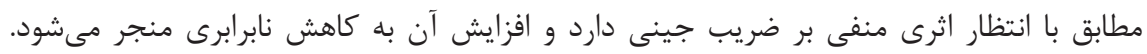

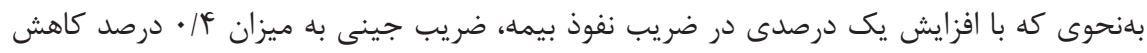

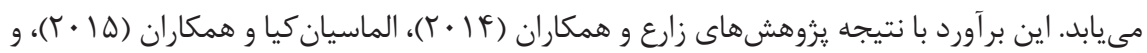
باغيان و همكاران (Y V • (Y) ساز Fار است. بديهى است كه به واسطه افزايش ضريب نفوذ بيمه بسيارى از مشكلات اقتصادى ناشى از عواملى مانند مركومير، كهولت، معلوليت، و از كارافتادگى تا حدودى تعديل مى گردد. همان گونه كه در بخش ادبيات موضوع به آن اشاره شد، افزايش در ضريب نفوذ با كاهش ريسك در سرمايهَذارى و مبادلههاى تجارى به افزايش سرمايهَذارى و رشد اقتصادى منجر برد

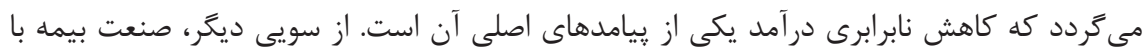


توجه به سهم קشمگير خود از درآمد جامعه، قادر است با استفاده از منابع مالى سرشار بلدستآمده،

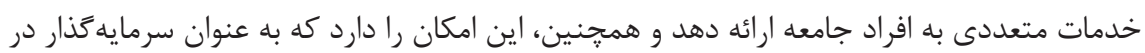
اجراى طرحهاى مختلف عمرانى و زيربنايى منشا خدمات شوند. بدين ترتيب، هرجقدر شركتهاي بيمه در جمعآورى منابع مالى و تجهيز و تخصيص اين منابع با كارايى بيشترى عملى عمل كنند، به رشد ريد هرجه بيشتر صنعت بيمه و در نهايت كل اقتصاد منجر مى شود. شاخص قيمت مصرفكننده نيز مطابق با انتظار اثرى مثبت بر ضريب جينى و به تبع آن اثر منفى ميى مئى

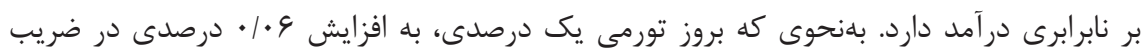

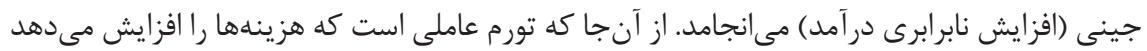

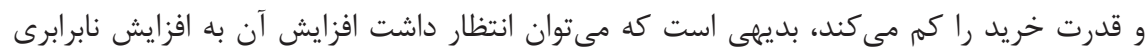

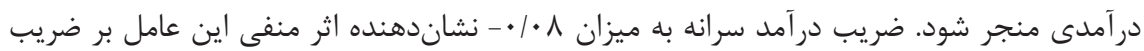

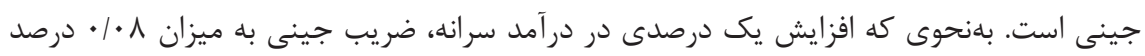

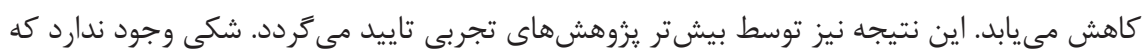

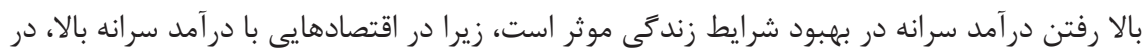

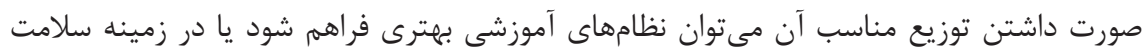

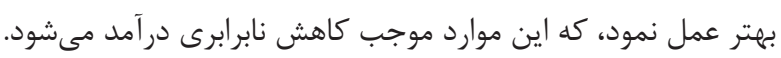

جدول بّ: نتايج بر آورد الكوى پايه به روش تشتاورهاى تعميميافته

\begin{tabular}{|c|c|c|c|}
\hline \multicolumn{4}{|c|}{ متغير وابسته: ضريب جينى } \\
\hline سطح احتمال & آماره & 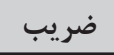 & متغير هاى توضيحى \\
\hline$\cdot / \cdots$ & $G N / D$ & $\cdot|4| Q$ & لكاريتم متغير ضريب جينى باوقفه \\
\hline$\cdot 1 \cdot \cdot 1$ & $-r / 1 \Lambda$ &.$- / \cdot$ et & لكاريتم ضريب نفوذ بيمه \\
\hline$\cdot / \cdots$ & $-F / 19$ & $-\cdot / \cdot \wedge 9$ & ل لعاريتهم در آمد سرانه \\
\hline$\cdot / \cdot 1$ & $4 / \cdot 9$ & .1 .94 & لكاريتم شاخص قيمت مصرفكننده \\
\hline سطح احتمال & \multicolumn{2}{|c|}{ مقدار آماره آزمون } & آزمون ساركان \\
\hline
\end{tabular}


ضريب نفوذ بيمه، شاخص قيمت مصرفكننده، و درآمد سرانه به مانند برآورد الكَى پايه است.

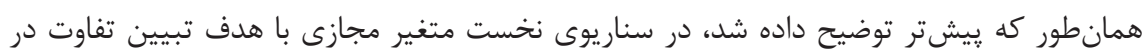

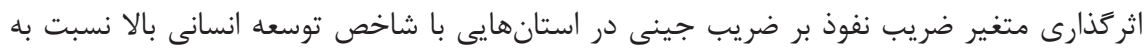
ساير استانها لحاظ مىشود. ضريب برآوردى متغير مجازى معنادار است و نشان مى دهد كه تفاوت معنادارى در اندازه اثرگذارى ضريب نفوذ بيمه بر ضريب جينى در دو گروه از استانها وجود دارد.

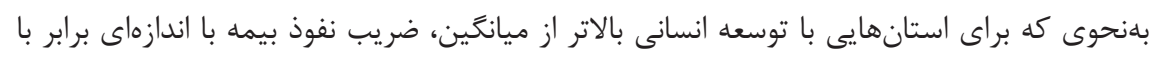

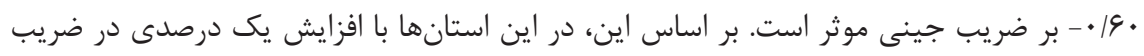

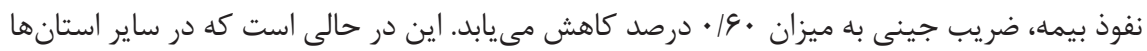

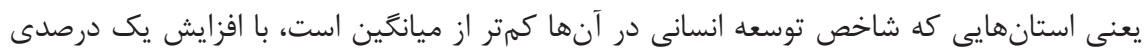

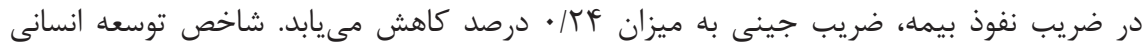
دربرگيرنده سه شاخص درآمد سرانه، اميد به زندگى، و سطح تحصيلات است. به هر ميزان كه افراد از درآمد بالاترى برخوردار باشند، حاضرند مبلغ بيشترى برده براى برخوردارى از خدمات متنوع بيمه

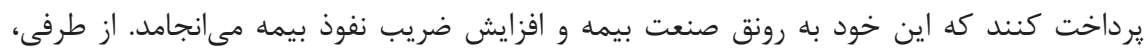
با توجه به مخاطرات موجود در سرمايه گذارى و انواع فعاليتهاى اقتصادى، فراهم كردن بسترهاى

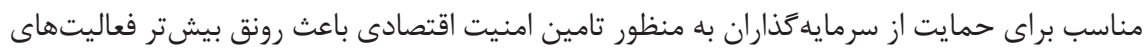

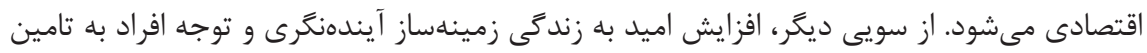

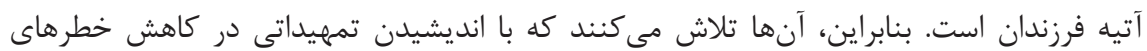
احتمالى و ساخت آيندهاى روشن بكوشند. سطح تحصيلات نيز نقش مستقيمى بر افزايش بهرهكيرى

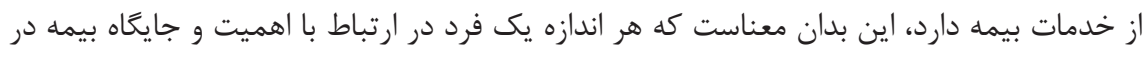

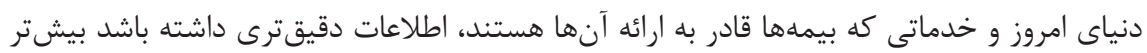
و بهتر مىتواند از خدمات بيمه بهرهمند شود. علاوه بر اين، افزايش سطح دانش و تحصيلات باعث

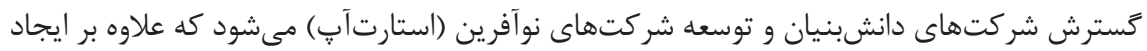

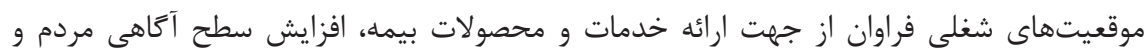

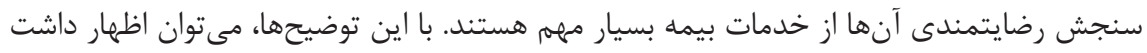
كه افزايش در سطح توسعه انسانى به افزايش ضريب نفوذ بيمه منجر مىشود كه خود موجب كاهش نابرابرى درآمد مى 
جدول †: نتايج بر آورد سناريوى يكم به روش تشتاورهاى تعميم يافته

\begin{tabular}{|c|c|c|c|}
\hline \multicolumn{4}{|c|}{ متغير وابسته: للَاريتم ضريب جينى } \\
\hline سطح احتمال & آماره t & 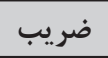 & متغير هاى توضيحى \\
\hline$\cdot 1 \cdot$ & $11 / V$ &.$/ 9 V 4$ & لكَاريتم متغير ضريب جينى باوقفه \\
\hline$\cdot|\cdot|+\mid$ & $-Y / \cdot \Delta$ & $-\cdot|Y F|$ & لكاريتم ضريب نفوذ بيمه \\
\hline$\cdot / \cdot$ & $-11 / 9$ & $-\cdot / \Lambda \Delta T$ & ل لكًاريتم درآمد سرانه \\
\hline$\cdot / \cdot$ & $1 \cdot / 4$ & $\cdot / V \Delta V$ & لعاريتم شاخص قيمت مصرفكننده \\
\hline.$/ \cdot r \Delta$ & $-T / T G$ & 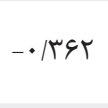 & 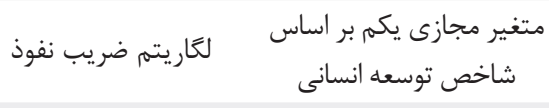 \\
\hline سطح احتمال & & مقدار & آزمون ساركان \\
\hline
\end{tabular}

در جدول (ه)، نتايج برآورد سناريوى دوم گزارش مىشود. در سناريوى دوم، نتايج اثرَذارى ضريب نفوذ بيمه، شاخص قيمت مصرفكننده، و در آمد سرانه مشابه با برآورد الكَىى يايه و سناريوى يكمى است.

جدول ه: نتايج بر آورد سناريوى دوم به روش تشتاورهاى تعميميافته

\begin{tabular}{|c|c|c|c|c|}
\hline \multicolumn{5}{|c|}{ متغير وابسته: ضريب جينى } \\
\hline سطح احتمال & آماره t & 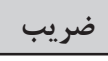 & وضيحى & متغير هاي \\
\hline$\cdot 1 \cdot \cdot$ & $1 T / 9$ & .1949 & ب جينى باوقفه & لخاريتم متغير ض \\
\hline$\cdot 1 \cdot$ & $-0 / 94$ &.$- / 499$ & نفوذ بيمه & ل لمَاريتم ضر \\
\hline$\cdot / \cdots$ & $-V / 1$ & $-.194 V$ & ل مد سرانه & لماريتهم د \\
\hline$\cdot 1 \cdot$ & $\mathrm{V} / \mathrm{T}$ & $\cdot \mid \Delta \wedge \hat{F}$ & ت مصرفكننده & لكاريتم شاخص ف. \\
\hline$\cdot 1 \cdot \cdot 1$ & $-\varphi / \varphi \Delta$ & -.1 .99 & لحَاريتم ضريب نفوذ & متر اساس ضريب مجازى دوم نفوذ \\
\hline سطح احتمال & \multicolumn{2}{|c|}{ 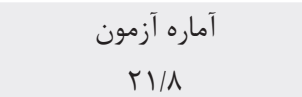 } & \multicolumn{2}{|c|}{ آزمون ساركان } \\
\hline
\end{tabular}

همانطور كه پِيشتر توضيح داده شد، در سناريوى دوم متغير مجازى با هدف تبيين تفاوت در

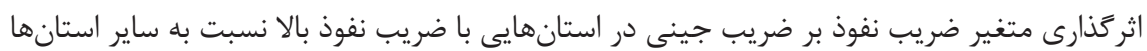


لحاظ مىشود. ضريب برآوردى اين متغير مجازى نيز معنادار است و نشان مىدهد كه تفاوت معنادارى

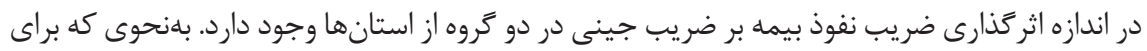

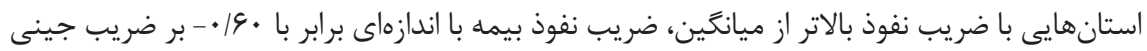
موثر است. بر اساس اين، در اين استانها با افزايش يك درصدى در ضريب نفوذ بيمه، ضريب جين جينى به

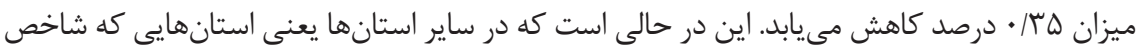

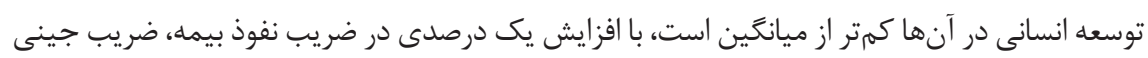

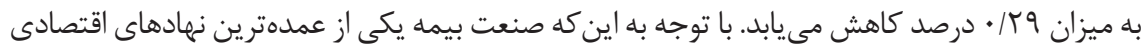

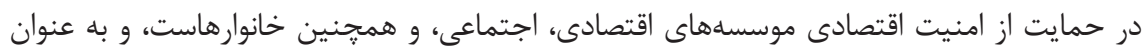
ابزارى براى تامين خسارت و انتقال ريسك زمينهساز رشد حجم مبادلههاى تجارى و سرمايهگذارى، بلهويزه در مواقع بحرانى مانند دوران ركود و تورم شناخته مىشود، بر اساس اين، افزايش ضريب نفوذ بيمه با كاهش ميزان ريسك، موجب رونق فعاليتهاى اقتصادى، افزايش سطح اشتغال، و به تبع آن

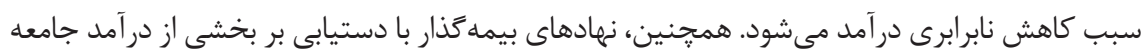

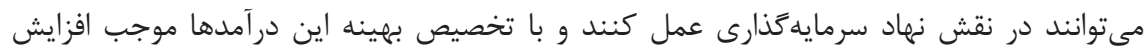
سرمايهَذارى و رشد اقتصادى شوند. با اين توضيح، مىتوان اظهار داشت كه افزايش در اندازه ضريب نفوذ بيمه، به تقويت اثركذارى ضريب نفوذ بيمه بر كاهش نابرابرى در آمد منجر مى بـودي.

\section{بحث و نتيجه كيرى}

اگرجه بخشهاى قابلتوجهى از يزوهشهاى اقتصادى به مطالعه و شناسايى تعيينكنندهاى رشد اقتصادى اختصاص دارد، ولى توزيع در آمد حاصل از رشد اقتصادى نيز از اهميت زيادى برخوردار است. مصرف سرانه، رفاه اقتصادى، آموزش، و بهداشت از جمله متغيرهايى هستند كه به جِكونكى توزيع در آمد بستكى دارند.

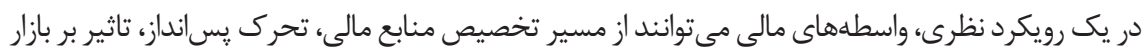

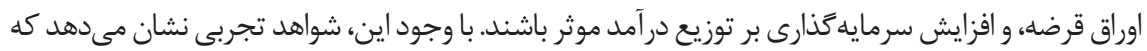

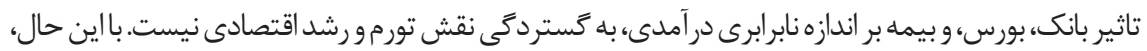

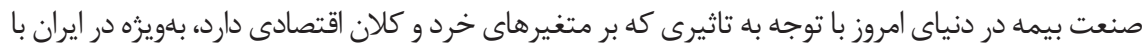

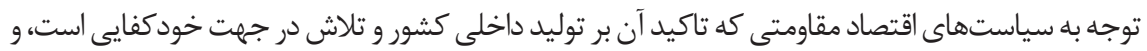
همجٍنين برنامه ششم توسعه اقتصادى، اجتماعى، و فرهنكى كشور كه از بيمه و فقر به عنوان يكى از ينج محور 
در اين يزوهش، تاثير بيمه بر نابرابرى درآمد در ايران مورد آزمون تجربى قرار مى گيرد. براى

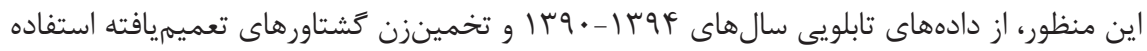
مىشود. در يزوهش حاضر، به بررسى ميزان اثركذارى ضريب نفوذ بيمه بر نابرابرى يرداخته مىشود. نتايج يزوهش بر مبناى برآورد يك الكوى پايه و دو سناريو نشان مى دهد كه تورم مطابق با انتظار اثرى

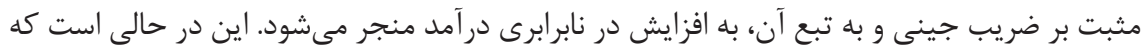

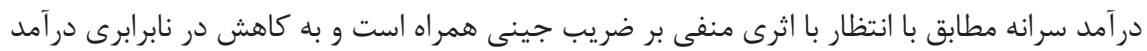

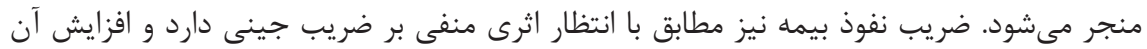

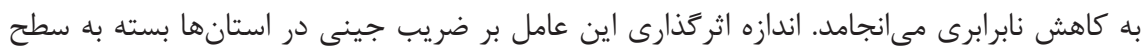

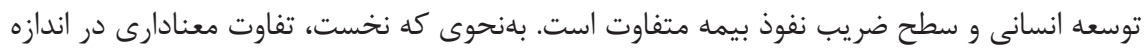

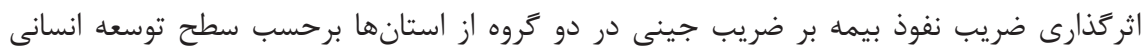
وجود دارد. با اين توضيح كه با افزايش در سطح توسعه انسانى اثركذارى ضريب نفوذ بيمه در كاهش

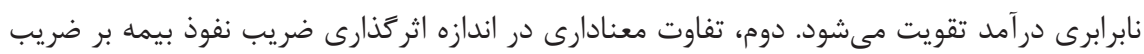

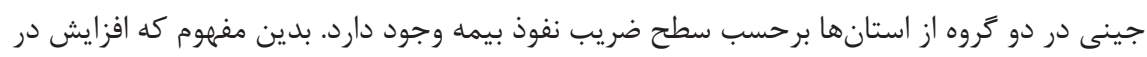
اندازه ضريب نفوذ بيمه، به تقويت اثرگذارى ضريب نفوذ بيمه بر كاهش نابرابرى درآمد منجر مى گرىدد.

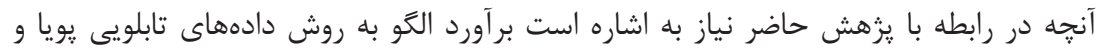

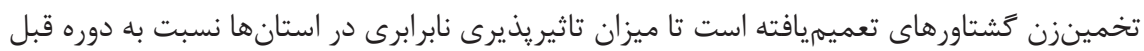
نيز مورد بررسى قرار گيرد. همجنين، استانهاى مورد بررسى به منظور تحليلى جامعتر بر مبناى معيارهاى اندازه شاخص توسعه انسانى و سطح ضريب نفوذ بيمه، تفكيك مىشوند. سوم، بهره گيرى از شاخص ضريب نفوذ بيمه به عنوان معيارى براى درك توسعه صنعت بيمه در مقايسه با كل اقتصاد كشور كه در يزوهشهاى مشابه كمتر مورد استفاده قرار كرفته است.

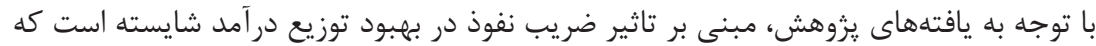

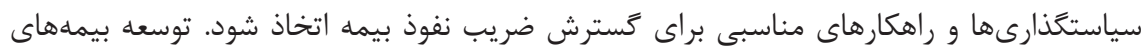
اعتبارى، تنوع در يرتفوى صنعت بيمه، گسترش شبكه فروش و بازاريابى، و ارائه طرحهاى حمايتى از

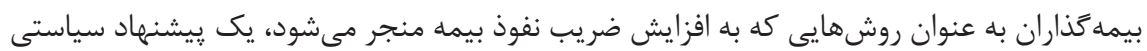
محسوب مىشود. همجنين، در مقايسه با سياستهاى انبساطى تقاضاى كل، سياستهاى تحريك

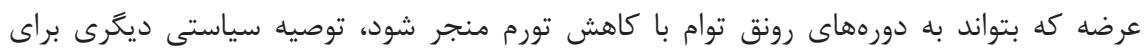

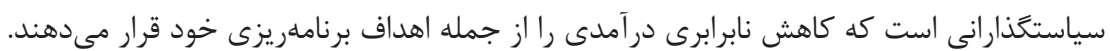




\section{منابع \\ الف) فارسى}

امينرشتى، نارسيس، و اصغرى، ليلا (•9 (1). بررسى نقش هزينهاى سلامت بر توزيع درآمد در ايران. مجله

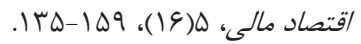

امينرشتى، نارسيس، و قربانى وليك جالى، عاطفه (Y (1) ). نقش نظام تامين اجتماعى بر توسعه انسانى در ايران.

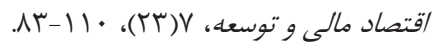

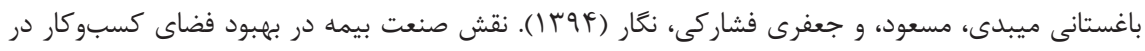

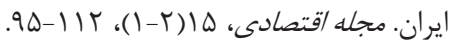

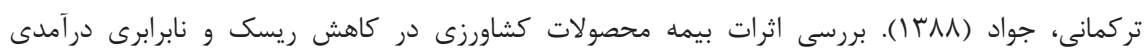

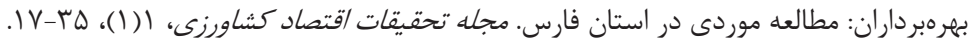

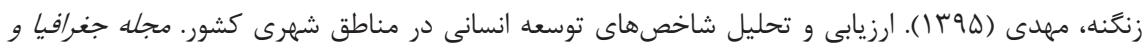

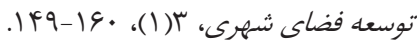

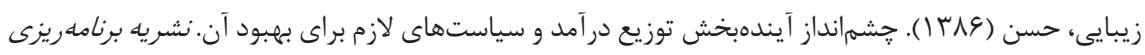

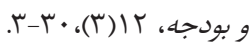

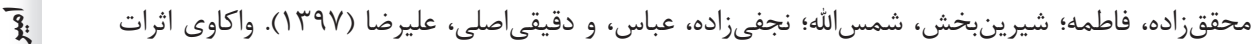

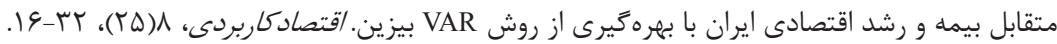

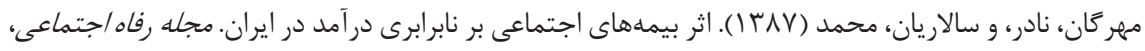
A

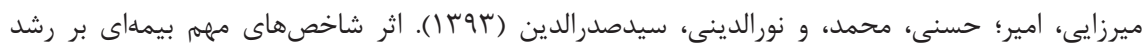

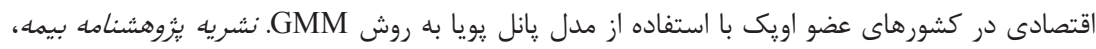

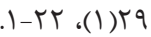

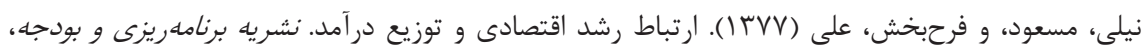

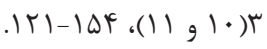

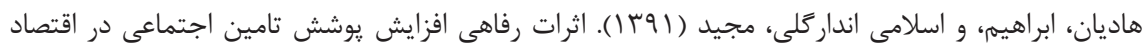

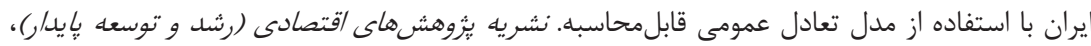




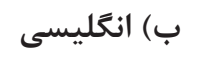

Akca, H., Ata, A. Y., \& Karaca, C. (2012). Inflation and Corruption Relationship: Evidence from Panel Data in Developed and Developing Countries. International Journal of Economics and Financial Issues, 2(3), 281-295.

Albanesi, S. (2007). Inflation and Inequality. Journal of Monetary Economics, 54(4), 10881114.

Alesina, A., \& Perotti, R. (1996). Income Distribution, Political Instability, and Investment. European Economic Review, 40(6), 1203-1228.

Alesina, A., \& Rodrick, D. (1994). Distribution Policies and Economic Growth. Quarterly Journal of Economics, Publisher: The MIT Press, 109(2), 465-490.

Almasiankia, A., Kavosi, Z., Keshtkaran, A., Jafari, A., \& Goodarzi, S. (2015). Equity in Health Care Financing Among Iranian Households. Shiraz E-Medical Journal, 16 (11-12), $1-7$.

Arellano, M., \& Bond, S. (1991). Some Tests of Specification for Panel Data: Monte Carlo Evidence and an Application to Employment Equations. The Review of Economic Studies, 58(2), 277-297.

Arena, M. (2008). Does Insurance Market Activity Promote Economic Growth? A Cross-Country Study for Industrialized and Developing Countries. Journal of Risk and Insurance, 75(4), 921-946.

Association of British Insurers (ABA). (2016). UK Insurance and Long-Term Savings Key Facts, abi.org.uk.

Baghian, N., Tayefi, E., Ranjbar, M., \& Eftekhari, A. (2017). Socioeconomic Inequality in Health Care Utilization: A Study of Service Utilization in Yazd, Iran. Evidence Based Health Policy, Management and Economics, 1(1), 2-8.

Baltagi, B. (2008). Econometric Analysis of Panel Data: John Wiley \& Sons.

Banerjee, A. V., \& Duflo, E. (2003). Inequality and Growth: What Can the Data Say? Journal of Economic Growth, 8(3), 267-299.

Barro, R. J. (2000). Inequality and Growth in a Panel of Countries. Journal of Economic Growth, 5(1), 5-32.

Buliř, A. (2001). Income Inequality: Does Inflation Matter? IMF Staff Papers, 48(1), 139159.

Caselli, F., Esquivel, G., \& Lefort, F. (1996). Reopening the Convergence Debate: A New Look at Cross-Country Growth Empirics. Journal of Economic Growth, 1(3), 363-389.

Chen, P. F., Lee, C. C., \& Lee, C. F. (2012). How Does the Development of the Life Insurance Market Affect Economic Growth? Some International Evidence. Journal of International Development, 24(7), 865-893.

Deininger, K., \& Squire, L. (1998). New Ways of Looking at Old Issues: Inequality and Growth. Journal of Development Economics, 57(2), 259-287.

Eicher, T. S., \& Turnovsky, S. J. (2003). Inequality and Growth: Theory and Policy Implications (Vol. 1): Mit Press.

European Systemic Risk Board (ESRB). (2015). Role of the Insurance Sector in the Economy. Report on Systemic Risks in The EU Insurance Sector, 1-20. 
Eurostat (2019). Income Poverty Statistics. Statistic explained

Galli, R. (2001). Is Inflation Bad for Income Inequality: The Importance of the Initial Rate of Inflation? Employment Paper.

Gordon, J., \& Becker, I. (2016). The Causes of Rising Income Inequality. The National Bureau of Economic Research (NBER).

Heer, B., \& Süssmuth, B. (2007). Effects of Inflation on Wealth Distribution: Do Stock Market Participation Fees and Capital Income Taxation Matter? Journal of Economic Dynamics and Control, 31(1), 277-303.

Hemmati, A. (2005). Insurance Market Cycles: Insurers and Carriers Looking to New Manners. Sanaat-E-Bimeh, 3(3), 191-201.

Hsiao, Mei-chu, W. (1987). Tests of Causality and Exogeneity between Exports and Economic Growth: The Case of Asian NICs. Journal of Economic Development, 12(2), 143-159.

Islam, N. (2003). What Have We Learnt from the Convergence Debate? Journal of Economic Surveys, 17(3), 309-362.

Kaestner, R., \& Lubotsky, D. (2016). Health Insurance and Income Inequality. Journal of Economic Perspectives, 30(2), 53-78.

Kuznets, S. (1955). Economic Growth and Income Inequality. The American Economic Review, 45(1), 1-28.

Leung, C. K. Y. (2001). Productivity Growth, Increasing Income Inequality and Social Insurance: The Case of China? Journal of Economic Behavior \& Organization, 46(4), 395-408.

Li, H., \& Zou, H.-f. (2002). Inflation, Growth, and Income Distribution: A Cross-Country Study. Annals of Economics and Finance, 3(1), 85-101.

Majeed, M. T. (2016). Economic Growth and Income Inequality Nexus: An Empirical Analysis for Pakistan. Kashmir Economic Review, 25(1), 1-11.

Majumdar, S., \& Partridge, M. (2009). Impact of Economic Growth on Income Inequality: A Regional Perspective. Ag Econ search. Research in Agricultural and Applied Economics Association (AAEA).

Mbazia, N. (2017). Inequality and Growth in Tunisia: Empirical Evidence on the Role of Macroeconomic Factors. Theoretical and Practical Research in Economic Fields (TPREF), 8(16), 153-160.

Motameni, M. (2015). Private Insurance and Income Inequality in Iran. Asian Economic and Financial Review, 5(3), 418-425.

Niyimbanira, F. (2017). Analysis of the Impact of Economic Growth on Income Inequality and Poverty in South Africa: The Case of Mpumalanga Province. International Journal of Economics and Financial Issues, 7(4), 254-261.

Panizza, U. (2002). Income Inequality and Economic Growth: Evidence from American Data. Journal of Economic Growth, 7(1), 25-41.

Romer, C. D., \& Romer, D. H. (1998). Monetary Policy and the Well-Being of the Poor. The National Bureau of Economic Research (NBER). NO. 6793.

Rubin, A., \& Segal, D. (2015). The Effects of Economic Growth on Income Inequality in the US. Journal of Macroeconomics, 45(1), 258-273.

Siami-Namini, S., \& Hudson, D. (2019). Inflation and Income Inequality in Developed and 
Developing Countries. Journal of Economic Studies, 46(3), 611-632.

Skipper, H. D. (1997). Foreign Insurers in Emerging Markets: Issues and Concerns (Vol. 1): International Insurance Foundation Washington, DC.

Swiss, R. (2010). The Impact of Inflation on Insurers. Sigma Technical Report.

Tanzi, V. (2002). Globalization and the Future of Social Protection. Scottish Journal of Political Economy, 49(1), 116-127.

Walter, S. (2010). Globalization and the Welfare State: Testing the Microfoundations of the Compensation Hypothesis. International Studies Quarterly, 54(2), 403-426.

Zare, H., Trujillo, A. J., Driessen, J., Ghasemi, M., \& Gallego, G. (2014). Health Inequalities and Development Plans in Iran; An Analysis of the Past Three Decades (1984-2010). International Journal for Equity in Health, 13(42), 1-12.

Zhu, L., \& Clark, J. H. (2015). Inequality in Health Care Persists at the State Level, Especially in Red States with Diverse Populations. USApp-American Politics and Policy Blog, 15(2), 239-262. 